\title{
Evaluating WRF-Chem aerosol indirect effects in Southeast Pacific marine stratocumulus during VOCALS-REx
}

\author{
P. E. Saide ${ }^{1}$, S. N. Spak ${ }^{1}$, G. R. Carmichael ${ }^{1}$, M. A. Mena-Carrasco ${ }^{2}$, Q. Yang ${ }^{3}$, S. Howell ${ }^{4}$, D. C. Leon ${ }^{5}$, J. R. Snider ${ }^{5}$, \\ A. R. Bandy ${ }^{6}$, J. L. Collett ${ }^{7}$, K. B. Benedict ${ }^{7}$, S. P. de Szoeke $^{8}$, L. N. Hawkins ${ }^{9}$, G. Allen ${ }^{10}$, I. Crawford ${ }^{10}$, J. Crosier $^{10}$, \\ and S. R. Springston ${ }^{11}$ \\ ${ }^{1}$ Center for Global and Regional Environmental Research (CGRER), University of Iowa, Iowa City, Iowa, USA \\ ${ }^{2}$ Center for Sustainability Research, Universidad Andrés Bello, Santiago, Chile \\ ${ }^{3}$ Pacific Northwest National Laboratory, Richland, WA, USA \\ ${ }^{4}$ Department of Oceanography, University of Hawaii at Manoa, Honolulu, USA \\ ${ }^{5}$ Department of Atmospheric Science, University of Wyoming, Laramie, Wyoming, USA \\ ${ }^{6}$ Department of Chemistry, Drexel University, Philadelphia, PA, USA \\ ${ }^{7}$ Colorado State University, Department of Atmospheric Science, Fort Collins, CO, USA \\ ${ }^{8}$ Oregon State University, College of Earth, Ocean, and Atmospheric Sciences, Corvallis, OR, USA \\ ${ }^{9}$ Harvey Mudd College, Department of Chemistry, Claremont, CA, USA \\ ${ }^{10}$ Centre for Atmospheric Science, University of Manchester, Manchester, M13 9PL, UK \\ ${ }^{11}$ Brookhaven National Laboratory, USA \\ Correspondence to: P. E. Said (pablo-saide@uiowa.edu)
}

Received: 16 October 2011 - Published in Atmos. Chem. Phys. Discuss.: 4 November 2011

Revised: 9 February 2012 - Accepted: 8 March 2012 - Published: 29 March 2012

\begin{abstract}
We evaluate a regional-scale simulation with the WRF-Chem model for the VAMOS (Variability of the American Monsoon Systems) Ocean-Cloud-AtmosphereLand Study Regional Experiment (VOCALS-REx), which sampled the Southeast Pacific's persistent stratocumulus deck. Evaluation of VOCALS-REx ship-based and three aircraft observations focuses on analyzing how aerosol loading affects marine boundary layer (MBL) dynamics and cloud microphysics. We compare local time series and campaignaveraged longitudinal gradients, and highlight differences in model simulations with (W) and without (NW) wet deposition processes. The higher aerosol loadings in the NW case produce considerable changes in MBL dynamics and cloud microphysics, in accordance with the established conceptual model of aerosol indirect effects. These include increase in cloud albedo, increase in MBL and cloud heights, drizzle suppression, increase in liquid water content, and increase in cloud lifetime. Moreover, better statistical representation of aerosol mass and number concentration improves model fidelity in reproducing observed spatial and temporal variability in cloud properties, including top and base height, droplet concentration, water content, rain rate, optical depth (COD) and liquid water path (LWP). Together, these help to quantify confidence in WRF-Chem's modeled aerosol-cloud interactions, especially in the activation parameterization, while identifying structural and parametric uncertainties including:
\end{abstract}

irreversibility in rain wet removal; overestimation of marine DMS and sea salt emissions, and accelerated aqueous sulfate conversion. Our findings suggest that WRF-Chem simulates marine cloud-aerosol interactions at a level sufficient for applications in forecasting weather and air quality and studying aerosol climate forcing, and may do so with the reliability required for policy analysis.

\section{Introduction}

Clouds play a major role in Earth's radiative balance (Ramanathan et al., 1989; Cess et al., 1989). However, uncertainties in the processes that affect cloud optical properties and modify this balance are still high (Solomon et al., 2007). These processes are driven by the indirect climatic effects of aerosols (Lohmann and Feichter, 2005), which can modify cloud albedo (Twomey, 1991) and lifetime (Albrecht, 1989), evaporate clouds (Graß1, 1979), change thermodynamics in deep convective clouds (Andronache et al., 1999), increase precipitation in ice clouds (Lohmann, 2002), and change the surface energy budget (e.g., Liepert, 2002).

Low-level marine clouds have been shown to contribute substantially to cloud radiative forcing (Ramanathan et al., 1989). However, these clouds are not well represented by contemporary models (Wyant et al., 2010). Previous work 
has shown problems in the ability of global and regional models to accurately represent marine stratocumulus clouds (Vellore et al., 2007; Otkin et al., 2009; Wyant et al., 2010; Abel et al., 2010), leading to difficulties in predicting cloud cover on an operational basis (e.g., Shah et al., 2010). Some problems are thought to be related to boundary layer schemes generating insufficient vertical mixing, resulting in an unrealistically shallow cloud-topped boundary layer (Otkin and Greenwald, 2008). By comparison, Large Eddy Simulation (LES) models have been shown to more effectively describe stratocumulus clouds and their transitions (e.g., Feingold et al., 1998; Khairoutdinov and Kogan, 2000; Berner et al., 2011; Wang et al., 2010). Efforts have been made to couple models at both scales (regional and LES), obtaining accurate representation of stratocumulus (Zhu et al., 2010). However, operational use of these coupled models for numerical weather prediction (NWP) or climate studies is not yet feasible. Cloud data assimilation has been an alternative way to improve clouds in NWP (e.g., Vellore et al. 2006; Errico et al., 2007; Michel and Auligné, 2010).

Uncertainties in modeling aerosol indirect effects diminish our capability to generate reliable climate projections, to evaluate policy questions and geo-engineering proposals, and to provide accurate weather and air quality predictions. Including indirect aerosol effects has been shown to improve cloud representations in global models (Lohmann and Lesins, 2002), and a range of approaches in modeling them have been assessed (Ghan and Easter, 2006). On the regional scale, including aerosol indirect effects tends to impact clouds optical properties (Chapman et al., 2009) and precipitation (Ntelekos et al., 2009), and often produces better cloud representation by optical properties, dynamics and microphysics (Gustafson et al., 2007; Q. Yang et al., 2011). The LES scale has been able to show the effect on cloud structure by different cloud condensation nuclei (CCN) loadings, and effectively simulate the dynamics of open cells, "pockets of open cells," and closed cell marine clouds (Wang and Feingold, 2009a, b).

Intensive measurement campaigns provide a wealth of observations that present the opportunity to evaluate models and to identify, quantify, and hopefully reduce these uncertainties. The VAMOS Ocean-Cloud-Atmosphere-Land Study Regional Experiment (VOCALS-REx, Wood et al., 2011) was an international field program designed to make observations of poorly understood but critical components of the coupled climate system of the southeast Pacific on the coast of Chile and Peru. Reactive gas and aerosol observations show a marked longitudinal gradient from elevated values close to shore due to polluted conditions to cleaner remote conditions (Allen et al., 2011), while cloud properties correlate to some extent with this gradient (Bretherton et al., 2010). Model evaluation studies emerging from the campaign have identified difficulties in accurately representing MBL and stratocumulus clouds (Abel et al., 2010; Sun et al., 2010; Andrejczuk et al., 2011) without considering aerosol feedbacks to meteorology. Q. Yang et al. (2011) present a comprehensive evaluation of the WRF-Chem system on a regional scale highlighting the effects of aerosol feedbacks, showing that the inclusion of aerosol-cloud interactions typically improve model performance in simulating cloud properties.

In this work, we build upon previous regional simulations including aerosol feedbacks using the WRF-Chem model. Several modeling studies have performed sensitivity analyses of the effects of aerosol loading on cloud properties (e.g., Chen et al., 2011). Starting from a base configuration, we find another configuration that better represents aerosol mass and number concentrations, and then analyze the impacts of these different aerosol loading on MBL dynamics and cloud microphysics, and compare them to observations and to the canonical conceptual model of warm cloud indirect effects. We perform an extensive evaluation of different aspects of the model representation, and identify areas for improvements and remaining problems.

\section{Methods}

For the purposes of defining representative spatial zones characterized by broadly internally similar thermodynamic aerosol and composition regimes (when averaged over the length of the VOCALS-REx campaign) we choose to use the three areas as defined by Bretherton et al. (2010) and Allen et al. (2011). These are the "coastal zone" (or "off shore", east of $75^{\circ} \mathrm{W}$ ), and the "remote zone" (west of $80^{\circ} \mathrm{W}$ ), with the two regions separated by a "transition zone" near the $78^{\circ} \mathrm{W}$ meridian $\left(75^{\circ} \mathrm{W}-80^{\circ} \mathrm{W}\right)$.

\subsection{WRF-Chem model configuration}

The WRF-Chem model simulates meteorology and atmospheric constituents, as well as their interactions (Skamarock et al., 2008; Grell et al., 2005). We configured WRFChem v3.3 with a combination of model structures, parametric choices, and input data to best represent marine stratocumulus conditions, atmospheric chemistry, and secondary aerosols, with the goal of future use in meteorological and air quality forecasting.

A $12 \times 12 \mathrm{~km}^{2}$ horizontal resolution domain is employed, covering $91^{\circ} \mathrm{W}-65^{\circ} \mathrm{W}$ longitude and $40^{\circ} \mathrm{S}-12^{\circ} \mathrm{S}$ latitude. This choice attempts to optimize between spatial resolution, critical for representing cloud dynamics, and complete coverage of the VOCALS region of the Southeast Pacific within the limitations of computing time. The domain accounts for most major Chilean and Peruvian anthropogenic sources shown in airmass trajectories (Chand et al., 2010) to impact VOCALS-REx observations, including the Andean cordillera, and covers the entire VOCALS-REx experimental domain (to $\sim 85^{\circ} \mathrm{W}$ ), with a margin towards the west and north to avoid excessive boundary condition influence on meteorology and atmospheric composition. Following recommendations by Wang et al. (2011), a 75-level vertical 
resolution was chosen to reduce MBL and cloud height underestimation. The first few levels are as in Saide et al. (2011) with $\sim 10 \mathrm{~m}$ thickness, and the average vertical layer spacing between $60 \mathrm{~m}$ and $3 \mathrm{~km}$ is $\sim 60 \mathrm{~m}$. In preliminary testing, this resolution produced accurate $\mathrm{MBL}$ and cloud heights for all longitudes, which were $\sim 100-300 \mathrm{~m}$ greater than the 39level resolution used in Saide et al. (2011).

Model structure was configured to combine modules included in contemporary WRF-Chem public release code that best represent known aerosol, cloud, and MBL processes and their couplings. Wherever possible, the most complete representations of complex physical and chemical processes were chosen. This application requires a boundary layer closure scheme that can make use of (and maintain numerical stability at) high vertical resolution, and can accurately represent the diurnal evolution of the MBL at low wind speeds. MellorYamada type schemes have generally exhibited good cloud representation under these conditions (Otkin and Greenwald, 2008; Zhu et al., 2010; Rahn and Garreaud, 2010). The MYNN level 2.5 scheme (Nakanishi and Niino, 2004) was chosen since it performed well in prior applications at this resolution over Chile (Saide et al., 2011). The Lin microphysics scheme (Chapman et al., 2009) and Goddard short wave radiation (Chou et al., 1998; Fast et al., 2006) were chosen to support aerosol direct, indirect, and semi-direct feedbacks to meteorology. Activation of aerosols from the interstitial to the cloudborne "attachment state" (Ghan and Easter, 2006) is based on a maximum supersaturation determined from a Gaussian spectrum of updraft velocities and the internally mixed aerosol properties within each aerosol size bin (Abdul-Razzak and Ghan, 2002). The updraft velocity distribution is centered in the model vertical wind component plus the subgrid vertical velocity diagnosed from vertical diffusivity. No cumulus scheme was used following the recommendation of Q. Yang et al. (2011). The RRTM longwave radiation scheme (Mlawer et al., 1997) was used. Gases and aerosols were simulated using the CBMZ gas-phase chemical mechanism (Zaveri et al., 1999; Fast et al., 2006) with dimethyl sulfide (DMS) reactions coupled to the 8-bin sectional MOSAIC (Zaveri et al., 2008) aerosol module. Seawater DMS concentration was set to $2.8 \mathrm{nM}$, following the VOCA Modeling Experiment Specification (http://www.atmos.washington.edu/ mwyant/vocals/ model/VOCA_Model_Spec.htm) and in agreement with measurements during VOCALS-REx (Hind et al., 2011). DMS is transferred to the air using sea-air exchange as in Liss and Merlivat (1986).

We chose emissions and chemical boundary conditions to best resolve spatial and temporal variability in aerosols and their precursors, taking into account a complete range of natural and anthropogenic emissions sources. Continental emissions of biogenic trace gases (e.g., isoprene) were predicted hourly by the MEGAN algorithm (Guenther et al., 2006), and daily biomass burning locations and fuel loadings were obtained from FIRMS MODIS fire detections (Davies et al.,
2009) and modeled hourly using WRF-Chem's plume rise model (Freitas et al., 2006, 2007). Volcanic and anthropogenic emissions, including point and area sources, were taken from the VOCA inventory described in detail by MenaCarrasco et al. (2012). Table 1 shows a summary of the sources of information for the emission inventories compiled for this research. In cases where particulate matter (PM) was not speciated, $10 \%, 30 \%$ and $70 \%$ were associated to elemental carbon, organic carbon and crustal aerosol, respectively. Chemical boundary conditions are obtained from 6-hourly MOZART global simulations (Emmons et al., 2010). MOZART fields were found to overestimate nearshore concentrations, so the model was started from clean initial conditions and spun up for 6 days to avoid biasing results. MOZART sulfur dioxide $\left(\mathrm{SO}_{2}\right)$ boundary conditions in the free troposphere (FT) were found to be underestimated, so a global minimum background level of $30 \mathrm{ppt}$ and a $50 \mathrm{ppt}$ minimum for heights over $3.5 \mathrm{~km}$ were set, in agreement with flight profile measurements in the remote region (Allen et al., 2011; Kazil et al., 2011). Sea salt aerosol emissions were modeled following Gong et al. (1997), but resultant concentrations from the default scheme were found to substantially overestimate ship-based measurements from the NOAA RV Ronald H. Brown (Ron Brown). In order to avoid misleading indirect effects due to these biases, submicron emissions were reduced by a factor of 10 and supermicron emissions were reduced by a factor of 2 , in line with campaign-averaged observations from the Ron Brown. Default WRF-Chem sea salt emissions do not consider sulfate coming from seawater, speciating sea salt as $\mathrm{Na}$ and $\mathrm{Cl}$ only. Wind-blown dust was not modeled, due to known high biases in WRF-Chem's online wind-blown dust emissions, concentrations, and resultant aerosol optical depth over land, and poor model representation of Andean dust composition. No organic sea emissions were considered in this study, as there was little to no evidence of these submicrometer particles during the campaign (Shank et al., 2012). Also, no secondary organic aerosols (SOA) were modeled as the fraction of SOA to total organic aerosol is thought to be low in this region ( $\sim 10 \%$, Kanakidou et al., 2005). New particle formation is modeled by the Wexler et al. (1994) scheme.

WRF-Chem simulations covered the entire VOCALS-REx campaign period, 15 October-16 November 2008, along with the extra 15 days that Ron Brown stayed in the domain (16-30 November). The model was run with an initial "chemical" spin-up period of 6 days with meteorology re-initialized from analyses at the middle of the modeling period using the previous chemical state. We found that 34 days of spin up are necessary to overcome the underestimated MBL height present in the National Centers for Environmental Prediction (NCEP) Final Analysis (FNL) from GFS (Sun et al., 2010), as only increasing vertical resolution is insufficient for debiasing the offshore MBL (Andrejczuk et al., 2011). 
Table 1. Summary of emissions inventories configurations. Areas are divided in metropolitan region, which is located on Central Chile, the rest of Chile and the rest of the domain.

\begin{tabular}{|c|c|c|c|c|}
\hline Geographical area & Sector & Inventory name & Species & Base year \\
\hline $\begin{array}{l}\text { Metropolitan } \\
\text { region }\end{array}$ & Mobile sources & SECTRA & $\begin{array}{l}\mathrm{PM}_{10}, \mathrm{PM}_{2.5}, \mathrm{CO}, \\
\mathrm{NO}_{\mathrm{x}}, \mathrm{SO}_{\mathrm{x}}, \text { VOCs, } \\
\mathrm{NH}_{3}\end{array}$ & 2010 \\
\hline $\begin{array}{l}\text { Metropolitan } \\
\text { region }\end{array}$ & Residential sources & $\begin{array}{l}\text { Chilean Ministry of } \\
\text { environment } \\
\text { DICTUC (2007) }\end{array}$ & $\begin{array}{ll}\mathrm{PM}_{10}, & \mathrm{PM}_{2.5}, \mathrm{CO}, \\
\mathrm{NO}_{\mathrm{x}}, & \mathrm{SO}_{\mathrm{x}}, \quad \mathrm{VOC}, \\
\mathrm{NH}_{3} & \end{array}$ & 2005 \\
\hline $\begin{array}{l}\text { Metropolitan } \\
\text { region }\end{array}$ & Point sources & $\begin{array}{l}\text { Chilean Ministry of } \\
\text { environment } \\
\text { DICTUC (2007) }\end{array}$ & $\begin{array}{ll}\mathrm{PM}_{10}, & \mathrm{PM}_{2.5}, \mathrm{CO}, \\
\mathrm{NO}_{\mathrm{x}}, & \mathrm{SO}_{\mathrm{x}}, \quad \mathrm{VOC}, \\
\mathrm{NH}_{3} & \end{array}$ & 2005 \\
\hline Rest of Chile & $\begin{array}{l}\text { Power plant } \\
\text { emissions }\end{array}$ & $\begin{array}{l}\text { Chilean power plant } \\
\text { emissions standard } \\
\text { KAS (2009) }\end{array}$ & $\begin{array}{ll}\mathrm{PM}_{10}, & \mathrm{PM}_{2.5}, \mathrm{CO}, \\
\mathrm{NO}_{\mathrm{x}}, & \mathrm{SO}_{\mathrm{x}}, \mathrm{VOC}, \\
\mathrm{NH}_{3} & \end{array}$ & 2009 \\
\hline Rest of Chile & Smelter emissions & $\begin{array}{l}\text { Chilean air quality } \\
\text { standards revision } \\
\text { Mena-Carrasco (2010) }\end{array}$ & $\begin{array}{ll}\mathrm{PM}_{10}, & \mathrm{PM}_{2.5}, \mathrm{CO}, \\
\mathrm{NO}_{\mathrm{x}}, & \mathrm{SO}_{\mathrm{x}}, \quad \mathrm{VOC}, \\
\mathrm{NH}_{3} & \end{array}$ & 2010 \\
\hline Rest of Chile & Mobile sources & $\begin{array}{l}\text { SECTRA regional } \\
\text { Corvalán et al. (2005) }\end{array}$ & $\begin{array}{l}\mathrm{PM}_{10}, \mathrm{PM}_{2.5}, \mathrm{CO} \\
\text { NOX, VOC }\end{array}$ & 2005 \\
\hline Rest of domain & $\begin{array}{l}\text { Total anthropogenic ex- } \\
\text { cluding power } \\
\text { and smelting }\end{array}$ & $\begin{array}{l}\text { EDGAR } 3.2 \\
\text { Olivier et al. (1994) }\end{array}$ & $\begin{array}{ll}\mathrm{PM}_{10}, & \mathrm{PM}_{2.5}, \mathrm{CO}, \\
\mathrm{NO}_{\mathrm{x}}, & \mathrm{SO}_{\mathrm{x}}, \quad \mathrm{VOC}, \\
\mathrm{NH}_{3} & \end{array}$ & 2005 \\
\hline Rest of domain & Total anthropogenic & Bond et al. (2004) & $\begin{array}{l}\text { Black carbon and or- } \\
\text { ganic carbon }\end{array}$ & 2005 \\
\hline
\end{tabular}

We found that aerosol wet deposition has a large influence over the modeling results. In the present version of WRF-Chem, in- and below-cloud wet removal of gases and aerosols in CBMZ-MOSAIC are modeled following Easter et al. (2004). This mechanism assumes that the removal processes are irreversible, and does not consider aerosol resuspension due to rain evaporation. This becomes an important issue for the Southeast Pacific during Austral spring, since most of the drizzle observed during VOCALS-REx evaporated before reaching the surface (Bretherton et al., 2010), leading to a great contrast between cloud base and surface rain rates. Thus, irreversible removal of aerosol by rain might create an unrealistically strong sink, which is supported by previous modeling results (Q. Yang et al., 2011). Kazil et al. (2011) implemented wet removal considering rain evaporation, but for a different modal aerosol approach and in the context of LES simulations. To assess the importance of modeled wet removal processes, we performed simulations where wet deposition was excluded, which results in higher aerosol loadings. This represents an upper limit to below cloud aerosol, and reflects the fact that low rain rates were observed at the sea surface $\left(0.01 \mathrm{~mm} \mathrm{~h}^{-1}\right.$ on average) during the VOCALS campaign (M. Yang et al., 2011), indicating that most rain evaporated before reaching the surface (Bretherton et al., 2010), suggesting nearly zero wet deposition. Thus, by turning off wet deposition the unrealistic sink of aerosol mass generated by not considering resuspension is removed. However, the effects in terms of number concentration are uncertain due to complex interactions: one droplet can collect thousands of particles by collision-coalescence but, as some have observed (Mitra et al., 1992; Feingold et al., 1996), only one aerosol is released after evaporation. Since rain rates increase as aerosol number concentration decrease, a cloud-scavenged ultra-clean layer can be generated which can lead to conditions of particle nucleation (Kazil et al., 2011) potentially recovering the number of particles lost before. Without an aerosol module that includes reversible wet deposition, and for the sake of studying the sensitivity to different aerosol loads, both simulations were conducted for the whole period. The simulation with wet deposition turned on is hereafter referred as the base run or "W", while the simulation without wet deposition is called "NW". Since W represents large aerosol removal, while NW no aerosol removal, we hypothesize that a model with a correct wet deposition scheme should be bounded by these two states.

\subsection{Observations}

The observations used for comparison are provided by the VOCALS-REx airborne and marine platforms. Carbon monoxide (CO), Ozone $\left(\mathrm{O}_{3}\right), \mathrm{SO}_{2}$, DMS gases; and sulfate $\left(\mathrm{SO}_{4}\right)$, nitrate $\left(\mathrm{NO}_{3}\right)$, ammonium $\left(\mathrm{NH}_{4}\right)$ and organic carbon (OC) interstitial aerosol (from AMS: non-refractory non-sea salt) observations collected by the NSF C-130, DoE G-1, FAAM BAe-146 aircrafts and Ron Brown are thoroughly described by Allen et al. (2011), Kleinman et al. (2012), M. Yang et al. (2011), and Hawkins et al. (2010), while C-130 cloud water composition measurement methods can 
be found in Benedict et al. (2012). The University of Wyoming $94 \mathrm{GHz}$ cloud radar (WCR) aboard C-130 provided radar reflectivities, which were then corrected (Bretherton et al., 2010) and converted to rainfall estimates using the Z-R relationship described in Comstock et al. (2004). This presents results consistent with Particle Measuring Systems (PMS) Two Dimensional Cloud Probe (2D-C) probe rainfall estimates during VOCALS (Bretherton et al., 2010). The WCR, along with an upward-pointing lidar (WCL) provided cloud top and base height estimates from the C-130 (Bretherton et al., 2010). Cloud top and base heights from Ron Brown were estimated using a millimeterwave cloud radar (MMCR) and a Vaisala CL31 ceilometer, respectively (de Szoeke et al., 2010). Capping inversion height $(\mathrm{CIH})$ was estimated as the height at which the temperature was a minimum, provided the relative humidity was at least $45 \%$ (Jones et al., 2011) in both Ron Brown soundings (Wood et al., 2011) and aircrafts vertical profiles. C-130 Gerber PVM-100 Probe cloud water content, PMS Cloud Droplet Probe (CDP) and Forward Scattering Spectrometer Probe (FSSP-100) cloud droplet number concentration, and PMS Passive Cavity Aerosol Spectrometer Probe (PCASP) accumulation mode aerosol number concentration observations used are described in Kazil et al. (2011) and Bretherton et al. (2010). BAe-146 cloud and accumulation mode aerosol measurements (Allen et al., 2011) were performed with similar instruments as in C-130 (Droplet Measurement Technologies (DMT) CDP-100, PCASP) while G-1 (Kleinman et al., 2012) used a DMT Cloud and Aerosol Sampling (CAS) probe and a PCASP, respectively. An intercomparison of the cloud microphysics probes fitted to BAe-146 and C-130 was performed on 31 October 2008 and 4 November 2008. The aircraft performed straight and level runs (of the order of 10's of km in length) through the same region of cloud approximately $5 \mathrm{~min}$ apart, finding that the number concentration, LWC and size distributions were similar within calibration and systematic error. However, G1 cloud microphysics measurements showed inconsistencies compared to other probes used (Kleinman et al., 2012) probably due to shattering of drizzle on CAS inlet (McFarquhar et al., 2007). On the Ron Brown, total number of particles over $13 \mathrm{~nm}$ was measured with a TSI 3010 Condensation Particle Counter. Cloud optical depth (COD), cloud liquid water path (LWP) and cloud effective radius were obtained from MODIS-Aqua retrievals.

\subsection{Performance statistics}

We present box and whisker plots of longitudinal profiles at $20^{\circ} \mathrm{S}$ (e.g., Fig. 1) in order to assess model performance in a consistent manner across trace gas, aerosol, and cloud properties, and to focus evaluation on the longitudinal gradients identified in VOCALS-REx observations as the most important characteristics of aerosol and low cloud regimes in the Southeast Pacific (Allen et al., 2011; Bretherton et al., 2010).
Table 2. Measure of model performance using data obtained from a box and whisker plot. A "match" is defined as a model (observation) median or mean being in between the two percentiles of the observation (model) distribution. Matches ranges from 4 (perfect match) to 0 (no match). An "overlap" is defined as when modeled and observed inner quartiles (boxes) or inner deciles (whiskers) overlap. Overlaps ranges from 2 to 0 . The final performance is assigned as the best of the three criteria.

\begin{tabular}{lccc}
\hline & $\begin{array}{c}\text { Matches in } \\
\text { the 25th-75th } \\
\text { percentile }\end{array}$ & $\begin{array}{c}\text { Matches in } \\
\text { the 10th-90th } \\
\text { percentile }\end{array}$ & Overlaps \\
\hline Excellent & 4 or 3 & - & - \\
Very good & 2 or 1 & - & - \\
Good & - & 4 or 3 & 2 \\
Fair & - & 1 or 2 & 1 \\
Poor & - & - & 0 \\
\hline
\end{tabular}

Here, we introduce a measure of accuracy deduced from these plots, hereafter referred to as the Box and Whiskers (BoW) metric and summarized in Table 2. We define a "match" as a model (observation) median or mean falling between the two prescribed percentiles of the observation (model) distribution. The first criterion (Table 2, column 1) uses the 25th and 75th percentiles (boxes in Fig. 1) and the second criterion (Table 2, column 2) uses the 10th and 90th percentiles (whiskers in Fig. 1). The third criterion (Table 2, column 3 ) is based on overlapping of the 25th and 75th (box overlapping) and 10th and 90th (whisker overlapping) percentile distributions. The net level of accuracy is determined from the sum of these three criteria, which is converted into a qualitative category: excellent, very good, good, fair and poor. Some of the advantages of the BoW method are that: it is independent of the variable being assessed; no absolute threshold of accuracy is specified for any variable; it is based on basic statistical parameters; it can easily be read from a box and whisker plot; and it transforms a quantitative measure of accuracy into a qualitative description. However, some issues could be encountered when the distributions are strongly skewed, as the mean could be found outside the inner quartile.

Statistics for cloud microphysics and aerosol number concentration were computed for aircrafts profile means instead of local point to point comparisons, since observed clouds could be in different levels than model values, generating mismatches with modeled and observed clouds both present, but at different levels. For estimating the modeled $117 \mathrm{~nm}$ to $3 \mu \mathrm{m}$ PCASP aerosol number concentration, values from bins 3 to 7 ( $156 \mathrm{~nm}$ to $2.5 \mu \mathrm{m}$ ) are integrated along with $42 \%$ of the second bin (78 to $156 \mathrm{~nm}$ ), which corresponds to the fraction over $117 \mathrm{~nm}$ using the logarithmic diameter.

Aircraft modeled and observed gases, aerosol mass, cloud heights and rain statistics were computed for one minute 

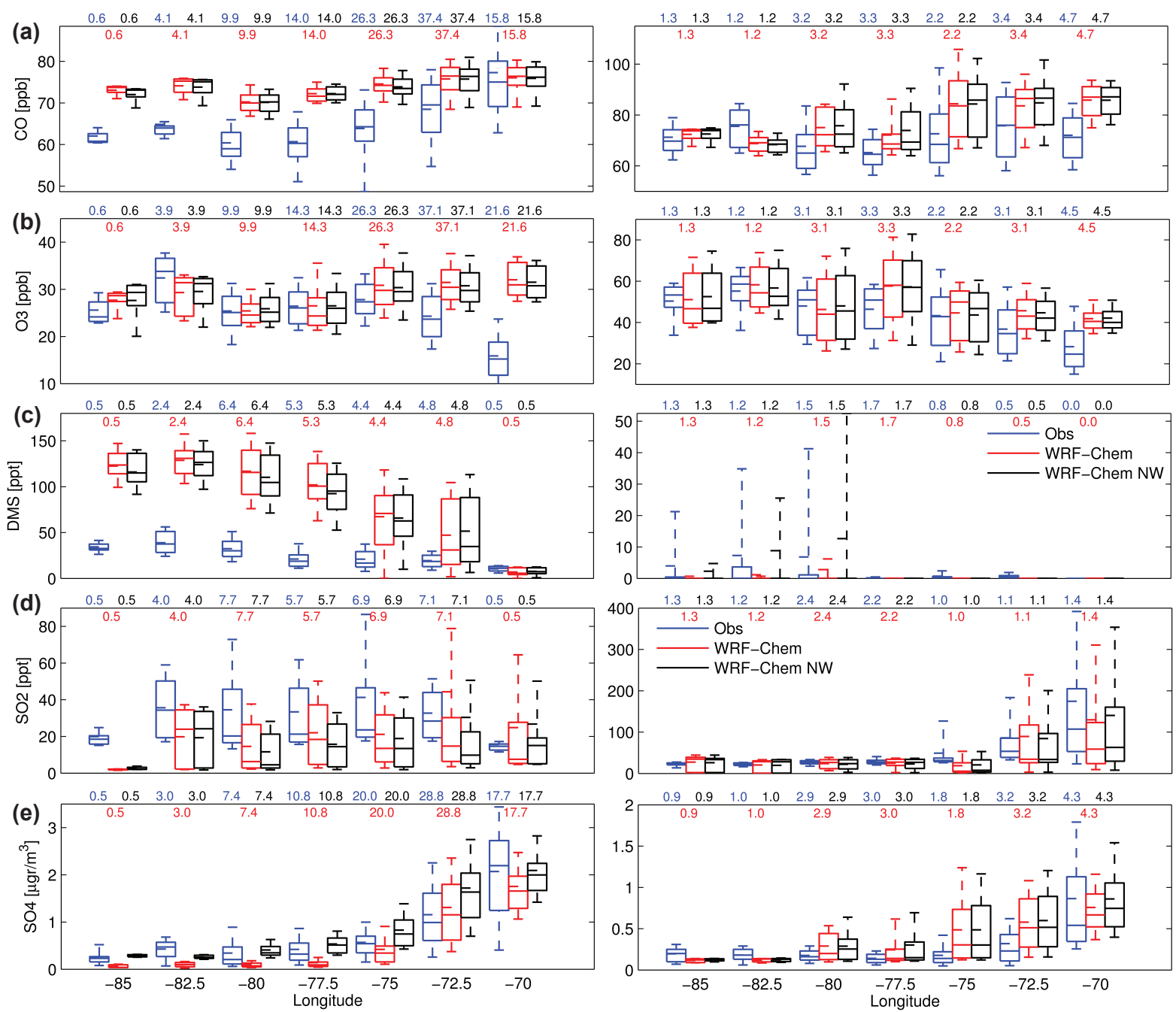

Fig. 1. Observed and modeled statistic for selected gaseous and aerosol species gridded into 2.5 degree longitudinal zones in between $22^{\circ} \mathrm{S}$ and $18^{\circ} \mathrm{S}$. For each zone, centre solid (dashed) lines indicate the median (mean), boxes indicate upper and lower quartiles with upper and lower decile whiskers. The sampling time in decimal hours in each longitude bin is indicated at the top. Left column and right column are for marine boundary layer (MBL) and free troposphere (FT), respectively.

average values, while Ron Brown statistics were computed for ten minute intervals. For the case of rain statistics, model results are not filtered for missing observations and vice versa as information on rain frequency can be extracted from the total sampling time in each longitude bin on the top of the box and whisker plots (e.g., Fig. 1). This creates minor inconsistencies; mainly in the $100 \mathrm{~m}$ height estimates, which was not measured in sub-cloud flight legs (Bretherton et al., 2010).

\section{Results and discussion}

We first focus on evaluating atmospheric concentrations of selected gases and aerosols for the base and NW simulations. Then, model performance is assessed for MBL dynamics and cloud microphysics. Finally, spatial and temporal variability in chemical transport and cloud effects are investigated on an episodic basis.

\subsection{Trace gas and aerosol evaluation}

Figure 1 shows aircrafts flight statistics for gaseous and aerosol concentration for selected species for the MBL and free troposphere (FT). For this plot, MBL concentrations were considered for heights lower than $1200 \mathrm{~m}$ or below cloud, and FT concentrations for heights in between 1700 and $3200 \mathrm{~m}$ in order to avoid cloud contamination (Allen et al., 2011). Trace gas data quality was assessed by intercomparison between aircrafts, obtaining 1.5 and $4 \mathrm{ppb}$ as the uncertainties for $\mathrm{CO}_{\text {and }} \mathrm{O}_{3}$, respectively (Allen et al., 2011). As seen in Fig. 1, MBL CO is overestimated across the entire 
modeled longitudinal range with the exception of the close to the shore bin where highly polluted plumes were detected by the G-1. Measurement uncertainty is well below these differences pointing to a model bias. Neglecting these nonresolved plumes, close to shore overestimation is probably due to a lower MBL than observed (see Sect. 3.2), while remote zone issues are likely due to overestimation of the MBL CO MOZART boundary conditions, as these air masses often had no contact with the continent for a long time period (Allen et al., 2011). However, we cannot rule out the possibility that a combination of overestimates in Central Chile anthropogenic emissions (e.g., Jorquera and Castro, 2010; Saide et al., 2009) and too much entrainment in the model could generate MBL concentrations similar to FT concentrations. The latter case is less likely, as it would have similarly affected $\mathrm{O}_{3}$. Remote FT CO shows very good to excellent performances driven mostly by MOZART boundary conditions over the east-central Pacific. Even though MBL CO shows poor to fair performance in BoW metrics, differences are no more than $15 \mathrm{ppb}$, and the observed longitudinal trend (decreasing towards remote zone) and spread $(<10 \mathrm{pbb})$ are often well simulated, indicating that transport in the MBL is resolved. The base and NW models show very small differences, attributable to changes in entrainment and MBL heights (see Sect. 3.2).

Figure $1 \mathrm{~b}$ shows $\mathrm{O}_{3}$ was well simulated for both the MBL and FT, with very good to excellent BoW metrics, and with similar spread. There is no clear longitudinal trend in either the model or the observations. An important point is that, as mentioned in Allen et al. (2011), the model resolves the $\sim 30 \mathrm{ppb}$ difference between MBL and FT and also the higher variability in the FT. The lower $\mathrm{O}_{3}$ in the MBL is the result of chemical destruction during the day, transport from FT during the night due to entrainment (M. Yang et al., 2011), and lower photolysis rates and temperatures under the cloud deck. Due to the ability of the model to correctly maintain the MBL to $\mathrm{FT} \mathrm{O}_{3}$ difference, we surmise that entrainment is simulated effectively. Hydroxyl radical $(\mathrm{OH})$ in VOCALS MBL was estimated by Yang et al. (2009) from the DMS budget and found to have maximum diurnal values of 3-5 $\times$ $10^{6}$ molecules $\mathrm{cm}^{-3}$. WRF-Chem showed $\mathrm{OH}$ peaks in the lower end of this range, at $\sim 2.5-3.35 \times 10^{6}$ molecules $\mathrm{cm}^{-3}$.

Statistics for gas and aerosol components of the sulfur cycle are shown in Fig. 1c-e. The C-130 measured FT DMS (Fig. 1c, right panel) was usually below the detection limit (5 ppt), as in the model. The spikes in DMS for the 75th to 90th percentile show times where the cloud top heights were $>1700 \mathrm{~m}$, which is better captured by NW as explained later. In general, MBL DMS has a high bias, with poor to fair BoW scores. As discussed by Q. Yang et al. (2011), this is likely related to an overestimation of DMS emissions due to overestimation of the modeled DMS ocean : atmosphere transfer velocity. Similarly to CO, and despite the emission bias, the modeled longitudinal trend is captured very well by the model. Ron Brown atmospheric DMS measurements
Table 3. Observed and modeled cloud chemistry statistics. Values where the observations (model) were inexistent were removed from the model (observations) statistics.

\begin{tabular}{lrrrr}
\hline & \multicolumn{2}{c}{ Observation } & \multicolumn{2}{c}{ NW model } \\
& Mean & Std dev & Mean & Std dev \\
\hline $\mathrm{pH}$ & 4.94 & 0.91 & 4.12 & 0.43 \\
$\mathrm{H}_{2} \mathrm{O}_{2}(\mu \mathrm{M})$ & 132.20 & 130.94 & 153.44 & 73.47 \\
$\left.\mathrm{TOC}(\mu \mathrm{g} \mathrm{CL})^{-1}\right)$ & 2028.9 & 571.0 & 1624.6 & 1953.0 \\
$\mathrm{Cl}^{-}(\mu \mathrm{N})$ & 855.3 & 1205.0 & 1220.2 & 1450.7 \\
$\mathrm{NO}_{3}^{-}(\mu \mathrm{N})$ & 72.77 & 120.39 & 28.41 & 32.22 \\
$\mathrm{SO}_{4}^{2-}(\mu \mathrm{N})$ & 298.35 & 465.94 & 133.42 & 152.71 \\
$\mathrm{Na}^{+}(\mu \mathrm{N})$ & 1204.6 & 2008.6 & 1253.3 & 1486.8 \\
$\mathrm{NH}_{4}^{+}(\mu \mathrm{N})$ & 90.65 & 163.89 & 2.51 & 2.88 \\
$\mathrm{Ca}^{2+}(\mu \mathrm{N})$ & 128.60 & 203.39 & 0.00 & 0.00 \\
\hline
\end{tabular}

showed higher values, in better agreement with the model but still lower. FT $\mathrm{SO}_{2}$ is also skillfully simulated, presenting mostly excellent BoW metrics and follows the observed longitudinal trend. FT Remote zone $\mathrm{SO}_{2}$ is mostly affected by boundary conditions, showing the importance of setting lower thresholds for influx from MOZART (see Sect. 2). In the MBL, the model usually exhibits very good performance, but cannot maintain the $\sim 20 \mathrm{ppt}$ lower threshold observed. When looking at the modeled $\mathrm{SO}_{2}$ diurnal cycle, the higher values are obtained after DMS photochemical destruction, but rapidly decay to values as low as $1 \mathrm{ppt}$ due to cloud processing and conversion to $\mathrm{SO}_{4}$ aerosol. Modeled conversion appears to occur at a higher rate than observed, which is investigated later in more detail. Finally, Fig. 1e shows sulfate mass concentrations statistics. $\mathrm{MBL} \mathrm{SO}_{4}$ clearly shows the impact of wet deposition as no remote zone $\mathrm{W}$ and $\mathrm{NW}$ model distributions overlap. The observations are typically closer to the NW results, and sometimes between the two simulations. As most of the rain evaporated before reaching the sea surface, we find that the NW results are more realistic, and that any overestimation could be due to the combination of high DMS emissions rates and high $\mathrm{SO}_{2}$ to $\mathrm{SO}_{4}$ cloud conversion yields. In the FT, both configurations show similar results with very good to excellent BoW performances. Other species play much smaller roles in aerosol composition. The model significantly underestimates $\mathrm{NH}_{4}$ (possibly due to emissions, which are poorly constrained in the region), estimates of $\mathrm{NO}_{3}$ are below detection limits as observed, and accurately predicts organic carbon (not shown). Most modeled $\mathrm{NO}_{3}$ is found in the coarser sectional bins, as it is displaced by $\mathrm{SO}_{4}$ in fine aerosol bins due to the low $\mathrm{NH}_{3}$ concentrations (Seinfeld and Pandis, 2006), and therefore rarely appears in aircrafts AMS observations, where aerodynamic diameter is capped at $500-700 \mathrm{~nm}$. Coarser aerosol is dominated by sea-salt, where $\mathrm{NO}_{3}$ displaces $\mathrm{Cl}$ creating a chloride deficit (Q. Yang et al., 2011). 


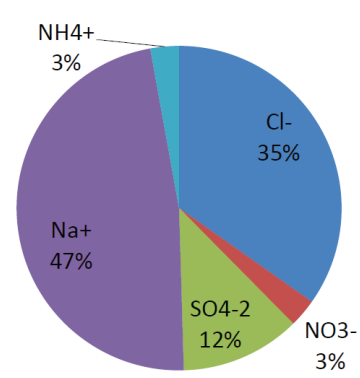

(a) C-130 Observations

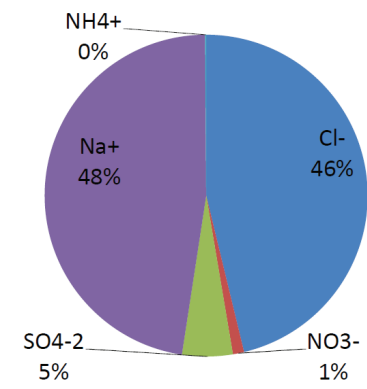

(b) WRF-Chem NW all bins

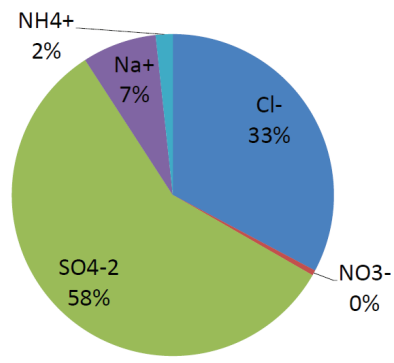

(c) WRF-Chem NW bins 1-3

Fig. 2. Pie charts for modeled ionic species for C-130 observations representing cloud composition (a) and the no wet deposition model (NW) using collection of wet aerosol along the flight track for all bins (b) and for bin 1, 2 and 3 (40 nm to $300 \mathrm{~nm}$ aerosol diameter) only (c). Units are in $\mu \mathrm{N}$.

In order to further explore $\mathrm{SO}_{2}$ to sulfate conversion processes, we compare cloud chemistry observations to the NW model (Fig. 2 and Table 3), as both models show similar cloud aerosol composition. Consistent with observations (Benedict et al., 2012), model results show that bulk (summing all sizes) cloud drop ion concentrations are dominated by sea salt, followed by sulfate (Fig. 2a, b). Bulk sulfate concentrations are underestimated, since sulfate coming from seawater is not modeled. As shown by Table 3, in general the model does a good job representing the mean and variability of the ion concentrations. The most notable problems are $\mathrm{Ca}^{+2}$, which is very low since no dust was modeled, and $\mathrm{NH}_{4}$, which is underestimated as it was in the AMS interstitial aerosol evaluation. Model $\mathrm{pH}$ shows the same tendency as observations, increasing towards the remote region as sulfate aerosol is more abundant close to shore (not shown). However, model $\mathrm{pH}$ is always under 5, while values up to 7 were observed, leading to underprediction in mean $\mathrm{pH}$ (Table 3). We found that the bulk model is extremely sensitive to chloride concentrations, as a decrease in only $5 \% \mathrm{in}^{-}$(as in observations) will increase average $\mathrm{pH}$ by 1 and increase single values up to $2.5 \mathrm{pH}$ units. This is important, as WRFChem uses a bulk cloud chemistry scheme (Chapman et al., 2009) and small variations in $\mathrm{Cl}^{-}$(thus in $\mathrm{pH}$ ) can generate a shift in the dominant mechanism of $\mathrm{SO}_{2}$ to sulfate conversion, from the roughly pH independent $\mathrm{H}_{2} \mathrm{O}_{2}$ reaction (Martin and Damschen, 1981) to the $\mathrm{O}_{3}$ reaction which increases in rate with $\mathrm{pH}$ (Hoffmann and Calvert, 1985), resulting in a speeding up of the $\mathrm{SO}_{2}$ to sulfate conversion and even further reductions in $\mathrm{SO}_{2}$ concentrations. However, as pointed out by M. Yang et al. (2011), most droplets nucleate from sulfate particles, so their $\mathrm{pH}$ will be acidic and dominated by the hydrogen peroxide reaction. This behavior for the majority of droplets is seen in modeled cloud water aerosol in the bins that dominate nucleation (Fig. 2c). We also see very low sea salt influence, as $\mathrm{Na}^{+}$percentage is low and $\mathrm{Cl}^{-}$is diffused into the droplet from $\mathrm{HCl}$ gas rather than entering the droplet as sea salt. All this implies that there is clear need for sized-resolved cloud chemistry (e.g., Fahey and Pandis, 2001), and that aqueous chemistry should be considered for nucleation and accumulation modes only (Kazil et al., 2011). Measurements considering the nature of the cloud condensation nuclei $(\mathrm{CCN})$ composition and size should also be performed (Bator and Collett, 1997). Analyzing the $\mathrm{H}_{2} \mathrm{O}_{2}$ pathway, $\mathrm{H}_{2} \mathrm{O}_{2}$ concentrations are slightly overestimated by the model (Table 3), which cannot explain the $\mathrm{SO}_{2}$ gap between model and observations. M. Yang et al. (2011) found that to close the $\mathrm{SO}_{2}$ budget, the Martin and Damschen (1981) $\mathrm{H}_{2} \mathrm{O}_{2}$ rate expression yielded best results, while other reaction rates were too fast to reach mass balance. We compared these rates to the McArdle and Hoffmann (1983) rates implemented in WRF-Chem, reaching the same answer, which could explain the difference in $\mathrm{SO}_{2}$. Another factor that influences increased $\mathrm{SO}_{2}$ depletion is the consistent overestimation of cloud fraction, as WRF-Chem NW shows average cloud fractions of $86 \%$ on the Ron Brown track, while the MMCR on board of Ron Brown (M. Yang et al., 2011) showed values of $67 \%$.

\subsection{MBL and marine Stratocumulus dynamics}

Box and whisker plots for cloud base and cloud top for the VOCALS-REx period are shown in Fig. 3a, b. The WRFChem NW model shows up to $200 \mathrm{~m}$ higher mean and median cloud top and base heights than the base model, bringing it closer to observations. The largest differences are found in the remote zone. The higher accumulation mode aerosol load obtained by NW allows for a less broken cloud deck with smaller droplet radius and less precipitation (see Sect. 3.3), which affects the MBL energy budget by decreasing average downward shortwave radiation (SW), upward surface heat flux and top of the atmosphere (TOA) outgoing longwave radiation (LW) by $50-60 \mathrm{~W} \mathrm{~m}^{-2}, \sim 3 \mathrm{~W} \mathrm{~m}^{-2}$ and $1-3 \mathrm{~W} \mathrm{~m}^{-2}$, respectively. Precipitation, $\mathrm{SW}$ absorption and LW cooling of clouds are the main drivers of entrainment in a cloud topped boundary layer, which in turn determines its cloud height. As shown by Pincus and Baker (1994), 

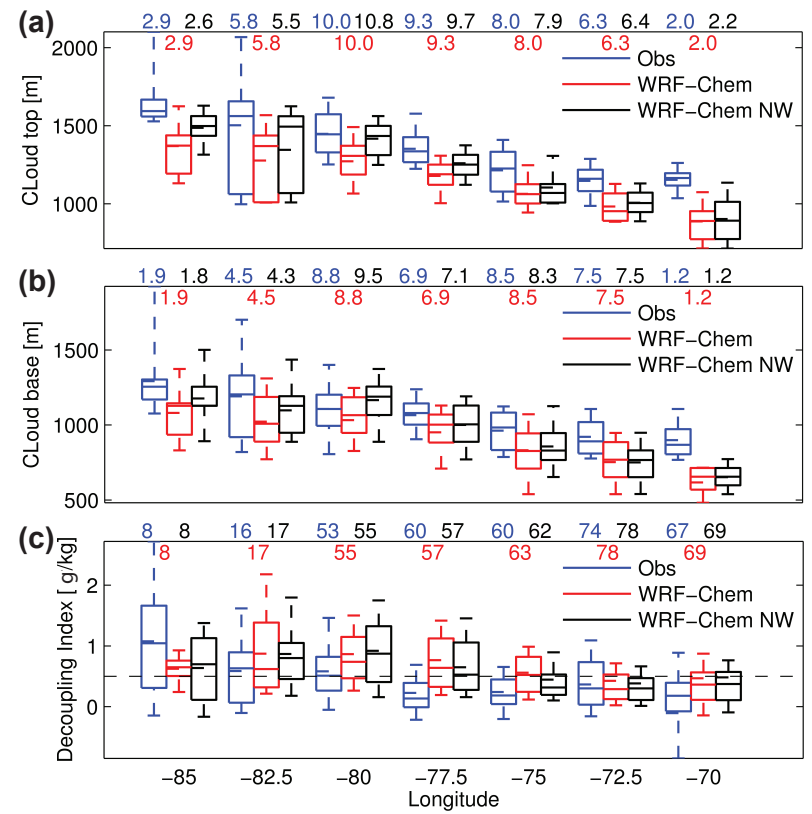

Fig. 3. Box and whisker plots for different variables derived from aircrafts measurements as in Fig. 1. (a) and (b): cloud top and bottom from U. of Wyoming radar (WCR) and lidar (WCL), respectively. (c) Decoupling index, the horizontal dashed line indicates the $0.5 \mathrm{~g} \mathrm{~kg}^{-1}$ decoupling threshold (see explanation on the text). The numbers above each zone represent sampling time in decimal hours for (a) and (b), and number of profiles for (c).

when number concentration of droplets increase, precipitation decreases, which increases entrainment. However, this also generates extra cloud water that produces thicker clouds that absorb more shortwave radiation (lower model downward SW), heating the layer and decreasing entrainment. Also, when clouds rise, cloud top temperature tends to decrease, decreasing LW cooling (model TOA outgoing LW decrease) and thus reducing entrainment. An overall increase in entrainment is achieved which cause cloud heights to rise (Pincus and Baker, 1994), in agreement with our results.

As aerosol loads increase for NW, the direct and semidirect effects are also expected to change. However, semidirect effects should not play an important role as BC observations (Shank et al., 2012) and model results show very low concentrations. A simulation where the aerosol radiation feedbacks were turned off using the NW configuration shows small differences for cloud top pressure $(< \pm 1 \%)$, cloud fraction $(< \pm 10 \%)$ and water content $(< \pm 10 \%)$, implying that indirect effects dominate under clean conditions like those observed during VOCALS-REx, where aerosol radiative effects become more important under heavily polluted conditions (Koren et al., 2008).

As seen in Fig. 3a, b, close to shore both simulations have large cloud height negative biases (fair to good BoW), as the coarse resolution is unable to resolve the steep topography and land-sea transition (Wang et al., 2011). In the remote zone the NW heights captured well the observations (mostly excellent BoW classifications) while the base model underestimated the heights (fair to excelent BoW scores). The NW model also better represents observed temperature and water vapor profiles in the remote zone both from aircraft profiles and ship-based soundings (not shown), as the typical MBL structure approaches the observed vertical profile. Even so, there are still some periods where the model does not simulate the very high cloud heights observed in the remote zone, as depicted by the 95th extremes of the observed distribution and as seen in the Ron Brown time series in Fig. 4, which are responsible for the lower model means. However, these periods of poor performance appear episodic, and there are periods where WRF-Chem NW does reach the observed heights (e.g., RF03 and RF05 on Fig. 4). Episodic underestimation of cloud heights is thought to come from meteorological boundary condition issues, as the model is unable to represent the high clouds condition occurring over several days (e.g., 19-23 November). The model shows good agreement with observations for a range of very different conditions: a 20S/POC drift flight (RF02) with very thin clouds, two flights to $85 \mathrm{~W}$ (RF03 and RF05) with different longitudinal cloud trends, and a coastal pollution survey flight (RF12) capturing the latitudinal gradient in cloud height.

In order to explore the model representation of MBL dynamics in more detail, a decoupling measure was computed. Jones et al. (2011) showed that an effective decoupling indicator can be calculated as the difference in total water mixing ratio $\left(q_{\mathrm{t}}\right.$, water vapor plus cloud water) between two levels: $25 \%$ and $75 \%$ of the capping inversion height $(\mathrm{CIH})$, considering a value below (above) $0.5 \mathrm{~g} \mathrm{~kg}^{-1}$ as a coupled (decoupled) MBL. Observed decoupling index and capping inversion height were obtained here from aircrafts vertical profiles following the method of Jones et al. (2011), and modeled values were obtained mapping the profiles and computing a modeled $\mathrm{CIH}$ and decoupling index. Figure $3 \mathrm{c}$ shows longitudinal statistics for all aircrafts flights. Both simulations represent several basic aspects of the observed decoupling. The modeled decoupling index is accurately predicted everywhere (very good to excellent BoW performance) but in the transition zone, where performance is lower but still good. On average, areas west of $78^{\circ} \mathrm{W}$ are decoupled while areas east of $78^{\circ} \mathrm{W}$ are coupled both in the observations and the model, and better represented by the NW simulation. The spread of the decoupling index on each zone is also well simulated, with noticeable higher spread west to $78^{\circ} \mathrm{W}$, as these zones alternate in between coupled and decoupled MBLs. Observations show a sharp longitudinal transition from coupled to decoupled MBLs, which is also represented by the model.

\subsection{Cloud microphysics}

Figure 5 shows statistics for cloud properties and for aerosol number concentration. Model cloud water representation is 


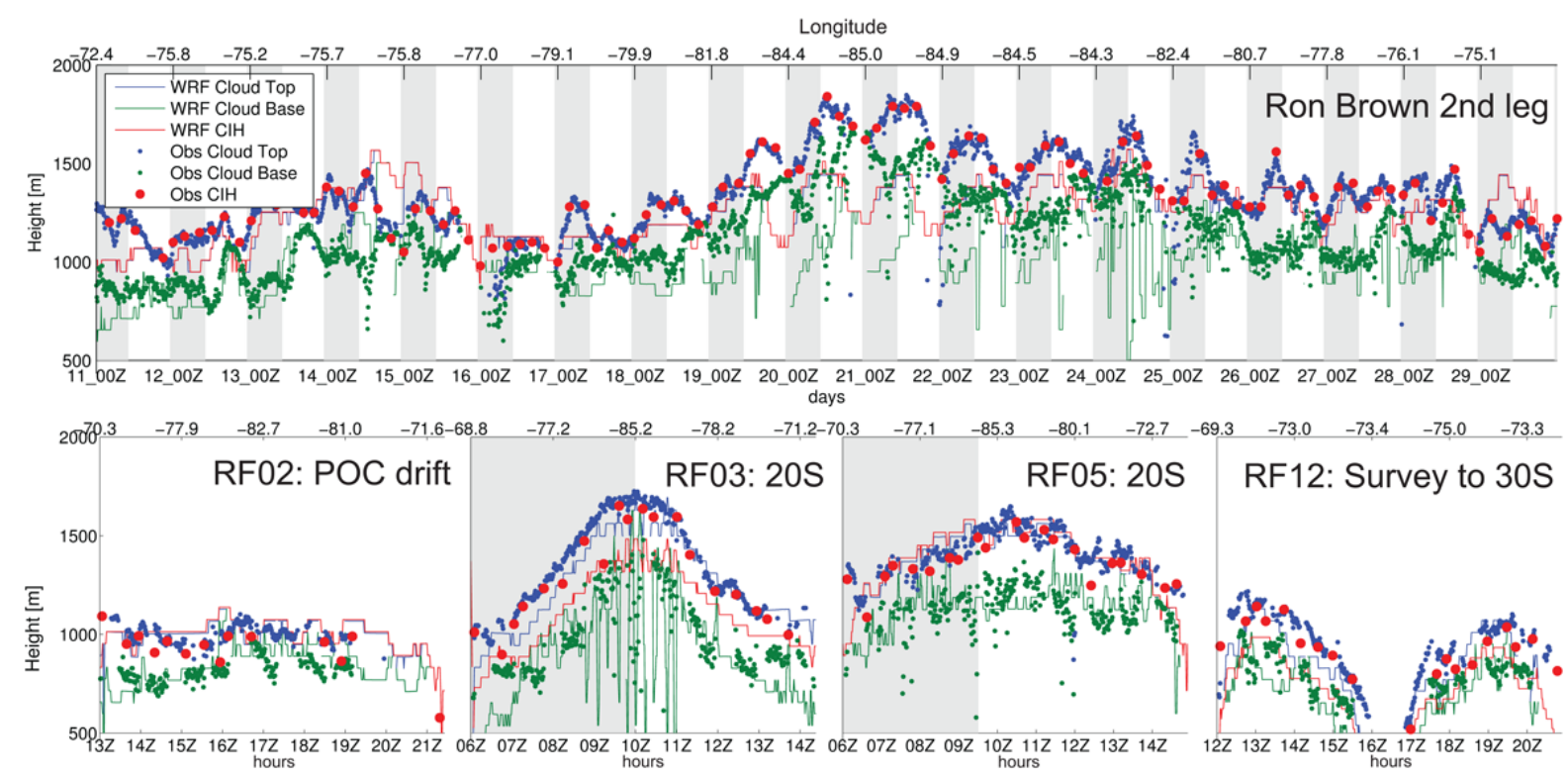

Fig. 4. Observed and NW model cloud bottom, cloud top and capping inversion height (CIH) time series from Ron Brown (top) and four C-130 flights (bottom). Shaded areas represent night periods.

very good to excellent (in BoW metrics) for both models (Fig. 5a), but the NW model typically shows higher amounts of cloud water than the base model as clouds are more permanent and thicker (consistent with the Twomey effect found by Albrecht, 1989). A clear difference is seen when analyzing number of droplets (Fig. 5b) where the increase in cloud albedo is more evident (Twomey, 1974) and modeled inner quartiles do not overlap over the remote region. This is a result of the difference in sub-cloud aerosol number concentration (Fig. 5c), where not even the modeled deciles overlap. Comparing observed and model droplet number and aerosol number concentration in the remote zone, the NW model presents excellent results while the base model is biased low (poor to good BoW scores), showing vast improvements in cloud microphysics by increasing the sub-cloud aerosol to near observed levels. We found consistency in the results, as when aerosol loads are relatively close to observations, the number of droplets also becomes closer to the observations. We thus conclude that the activation routine in WRF-Chem is consistent and reliable. The inability of NW to represent the lower end and spread of the cloud droplet and aerosol number distributions can be related to not considering wet deposition, as aerosol number is expected to decrease for intense sub-cloud rain events since a single droplet can collect a large amount of particles and release just one when evaporation occurs (Kazil et al., 2011). Close to shore overestimation of droplet number concentration by both simulations may be explained by the slight overestimation of aerosol number and also by the fact that the model finds that the aerosol number concentration in the $1 \mathrm{st}$ bin ( 40 to $78 \mathrm{~nm}$ in diameter) is an important contributor to activated particles. The latter is not captured by the PCASP aerosol number concentrations, as it only measures aerosol diameters over $117 \mathrm{~nm}$. Free troposphere aerosol number concentration (Fig. 5d) follows the same trend as in the MBL, with good to excellent BoW accuracy and few differences between the two simulations.

Rain estimates extracted from radar reflectivities and model statistics are shown in Fig. 6. Focusing on the cloud top (a) and cloud base (b) plots, it can be seen that the model captures in-cloud rain stratification, showing lower mean and median values for the cloud top. WRF-Chem also represents the longitudinal gradient in rain rate (Bretherton et al., 2010). The NW model tends to exhibit better agreement with observations, showing lower mean and median rainfall rates. The NW model has higher concentrations of activated particles and smaller effective droplet radius, which decrease autoconversion and suppress precipitation (Albrecht, 1989). The equilibrium reached in the base simulation is off since as more precipitation is produced, more particles are scavenged (and not recovered after evaporation), further reducing the number of particles and leading to even more precipitation in a reinforcing feedback. Besides showing higher precipitation rates, the base run also shows higher precipitation occurrence along the flight track (sampling time on the top of each plot), while the NW results tend to agree more closely with observations. At lower altitudes (500 and $100 \mathrm{~m}$ ), observed precipitation occurrence decreases, which is also captured by both models, with the NW model always showing lower occurrence. At $100 \mathrm{~m}$, the base model shows better agreement with remote observed rain rates and NW overestimates the mean and medium. Since the NW rain is scarcer, in agreement with observations, heavy drizzle events tend to skew 

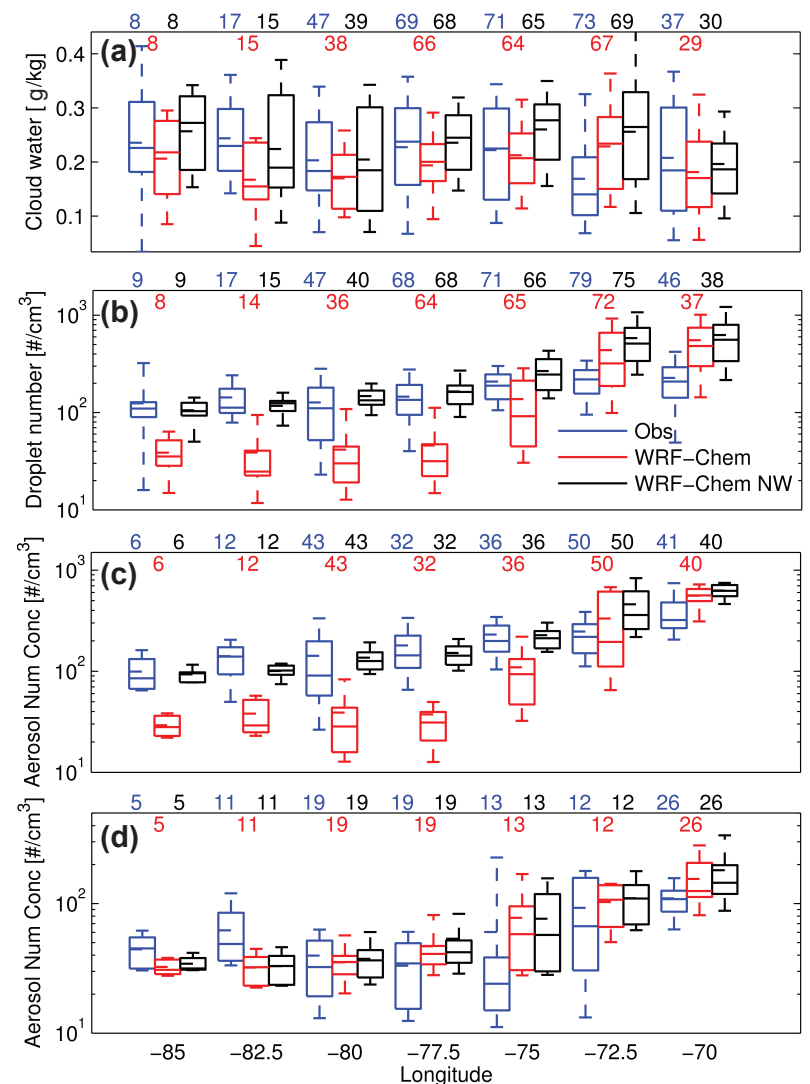

Fig. 5. Box and whisker plots for selected cloud properties and aerosol number concentration as in Fig. 1. (a) Profile mean cloud water content. (b) Profile mean number of droplets concentration. (c) and (d): marine boundary layer (MBL) and free troposphere (FT) mean profile aerosol number concentration. Number of profiles is indicated at the top of each longitude bin.

the distribution. However, modeled rain range given by the outer deciles agrees with the observations.

While episodic comparisons with in-situ observations are critical, it is also important to consider model performance for regional climatology, as the model should represent monthly mean values and their spatial features. Figure 7 shows COD and LWP for MODIS and both WRF-Chem simulations. Model COD was computed by first computing the effective radius as in Martin et al. (1994) and then COD as proposed by Slingo (1989) for the $0.64-0.69 \mu \mathrm{m}$ band, as the MODIS reference wavelength for this retrieval is $0.65 \mu \mathrm{m}$ (King et al., 2006). The base WRF-Chem model usually underestimates COD, while the NW model is closer to the observations. Several features are well represented: close to shore hotspots of COD around $17^{\circ} \mathrm{S}$ and $26^{\circ} \mathrm{S}$, a nearshore local COD minimum around 36S, and an increase in $\mathrm{COD}$ around $20^{\circ} \mathrm{S}$ from $80^{\circ} \mathrm{W}$ to $75^{\circ} \mathrm{W}$. In the remote zone $\left(83^{\circ} \mathrm{W}\right.$ to $\left.90^{\circ} \mathrm{W}\right)$, observed COD tends to fall between both models but closer to NW, for the same reasons presented before to explain episodic performance: the base model is

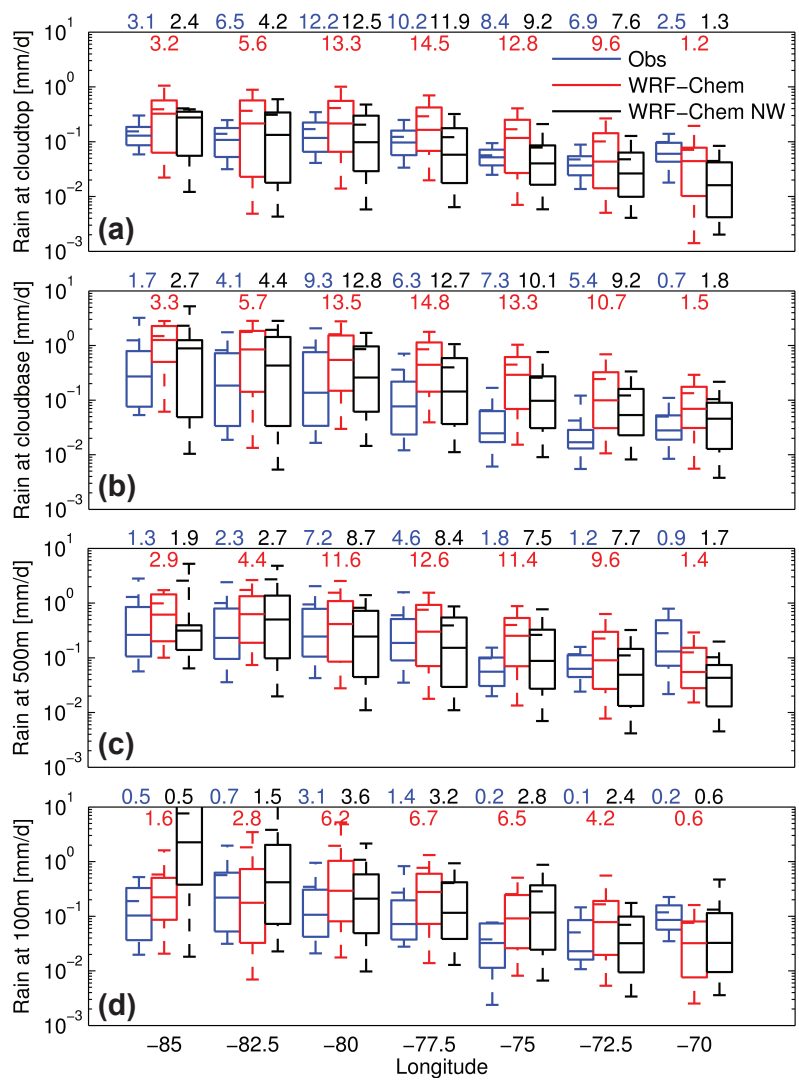

Fig. 6. Box and whisker plots for radar derived and modeled rain at different heights as in Fig. 1. (a) and (b) corresponds to rain rates just below the cloud top and at the cloud base while (c) and (d) corresponds to rain rates at fixed heights of 500 and $100 \mathrm{~m}$. The numbers above each zone represent sampling time in decimal hours.

unable to generate a thick enough cloud layer and drizzles too much, while the NW clouds do not dissipate when moving westwards, thereby increasing cloud lifetime (Albrecht, 1989). LWP path shows a different behavior, as both models underestimate MODIS LWP, probably due to a model bias in the Lin microphysics parameterization, as the Morrison scheme (Morrison and Pinto, 2005) generates higher LWP (Q. Yang et al., 2011), as discussed further in the text. However, NW model results consistently show higher values and a better agreement with observations.

\subsection{Aerosol feedbacks and relation to sources}

The Ron Brown provided a unique platform for continuous point measurements. Not only does the vessel have a much longer residence time in each regional model grid-cell than research aircraft, it also records the complete diurnal cycle at each location. One of the points where Ron Brown sampling efforts were focused was at $\left(20^{\circ} \mathrm{S}, 75^{\circ} \mathrm{W}\right)$, where it spent approximately 8 days, 4 days on each leg of the cruise. This area was found to be affected by coastal sources (Allen 

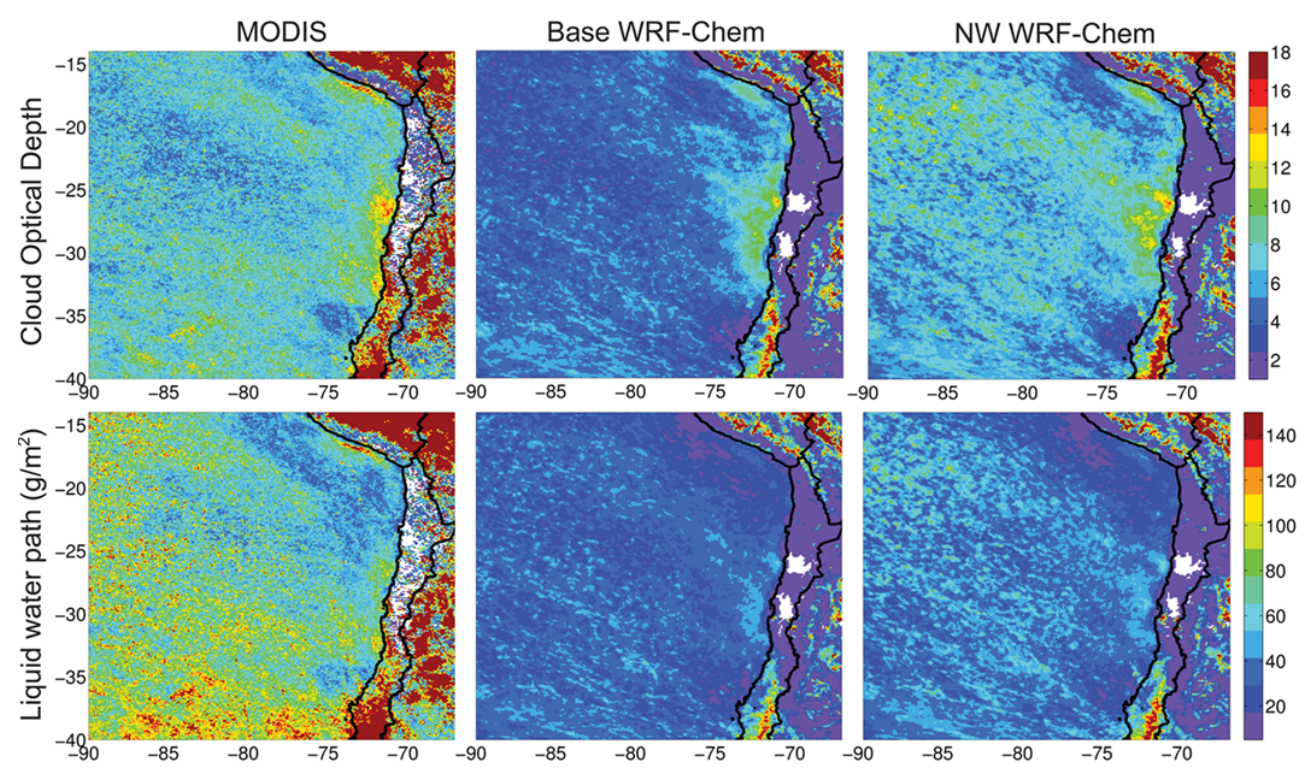

Fig. 7. MODIS-Aqua products and model monthly averages for the VOCALS period (15 October to 16 November). First and second row show cloud optical depth (COD) and liquid water path (LWP), respectively while first, second and third columns show MODIS, the base model and the no wet deposition (NW) model, respectively.

et al., 2011; Bretherton et al., 2010; Hawkins et al., 2010). To evaluate model performance and aerosol interactions, Fig. 8a compares total observed sulfate to the base and NW models. Observed values are closer to the NW model, but both models resolve most of the periods where $\mathrm{SO}_{4}$ concentrations increase over $1 \mu \mathrm{g} \mathrm{m}^{-3}$. As seen in Fig. 8b, the $\mathrm{SO}_{4}$ episodes are well correlated with aerosol number concentrations over $13 \mathrm{~nm}$ in diameter, a relationship also represented by the model. Observed aerosol number concentration is in the high range of the models because the lowest bin modeled is $40 \mathrm{~nm}$, and does not include the 13 to $40 \mathrm{~nm}$ window. These sulfate episodes do not follow any diurnal pattern, and are a constant factor affecting aerosol concentrations in this zone. Model results, including prior modeling by Spak et al. (2010) that only included anthropogenic sulfur emissions, clearly indicate that these peaks can be attributed to continental sources, usually coming from Central Chile. As an example, Fig. 8c shows the evolution of second bin (78 to $156 \mathrm{~nm}$ in diameter) $\mathrm{SO}_{4}$ (main contributor to aerosol number concentration) in a distinct pollution plume from the time emitted in Central Chile until it reaches the Ron Brown, 2 days after. When fresh, the maximum value of the plume is found on model level 17, around $650 \mathrm{~m}$ above sea level. At this height, it is transported by southeasterly trades (Rahn and Garreaud, 2010) until it makes contact with the MBL, where it starts entraining and $\mathrm{SO}_{2}$ to $\mathrm{SO}_{4}$ conversion is enhanced in clouds. Once in the MBL, lower wind speeds result in the plume taking a longer time to reach the Ron Brown location. In the $\mathrm{MBL}$, the plume receives additional $\mathrm{SO}_{4}$ contributions from DMS, as a near-shore DMS emissions hot spot is found off central Chile $\left(26^{\circ} \mathrm{S}-36^{\circ} \mathrm{S}\right)$ due to wind shear generated by the subtropical low-level jet (Garreaud and Muñoz, 2005; Muñoz and Garreaud, 2005). By performing a simulation without DMS initial conditions and emissions, we estimate the DMS contribution to sulfate to be from $15 \%$ to $25 \%$ in mass (which could be overestimated as shown in previous sections) by the time the plume reaches the Ron Brown location for the case analyzed, showing that these episodes are generated mainly by anthropogenic sources. The ability of these plumes to reach this zone is thought to be determined by the position of the surface pressure maximum of the Southeast Pacific Anticyclone (Spak et al., 2010).

Distant sources from Central Chile often have a visible footprint in $\mathrm{SO}_{4}$ mass and aerosol number concentration over the study domain, and these enhanced aerosols participate in cloud feedbacks such as drizzle suppression. Figure 9 shows curtain plots of radar reflectivity (proxy for precipitation) and aerosol number concentration for C-130 RF05 flight, showing very marked and correlated longitudinal gradients both on aerosol load and precipitation for NW and observed values. The base model (W) shows the same gradient (not shown), with higher rain rates in the remote region. Bretherton et al. (2010) argued that lack of drizzle near the coast is not just a microphysical response to high droplet concentrations; but other aspects such as lower LWP and thinner clouds (related to shallower and coupled MBL) can be comparably important. However, synoptic conditions present during RF05 flight were such that MBL height differences between off shore and remote zone weren't significant (cloud top and base heights differences less than $250 \mathrm{~m}$ and $200 \mathrm{~m}$ respectively, Fig. 4) and the remote region was not decoupled (no vertical gradients on aerosol concentrations inside the MBL, 

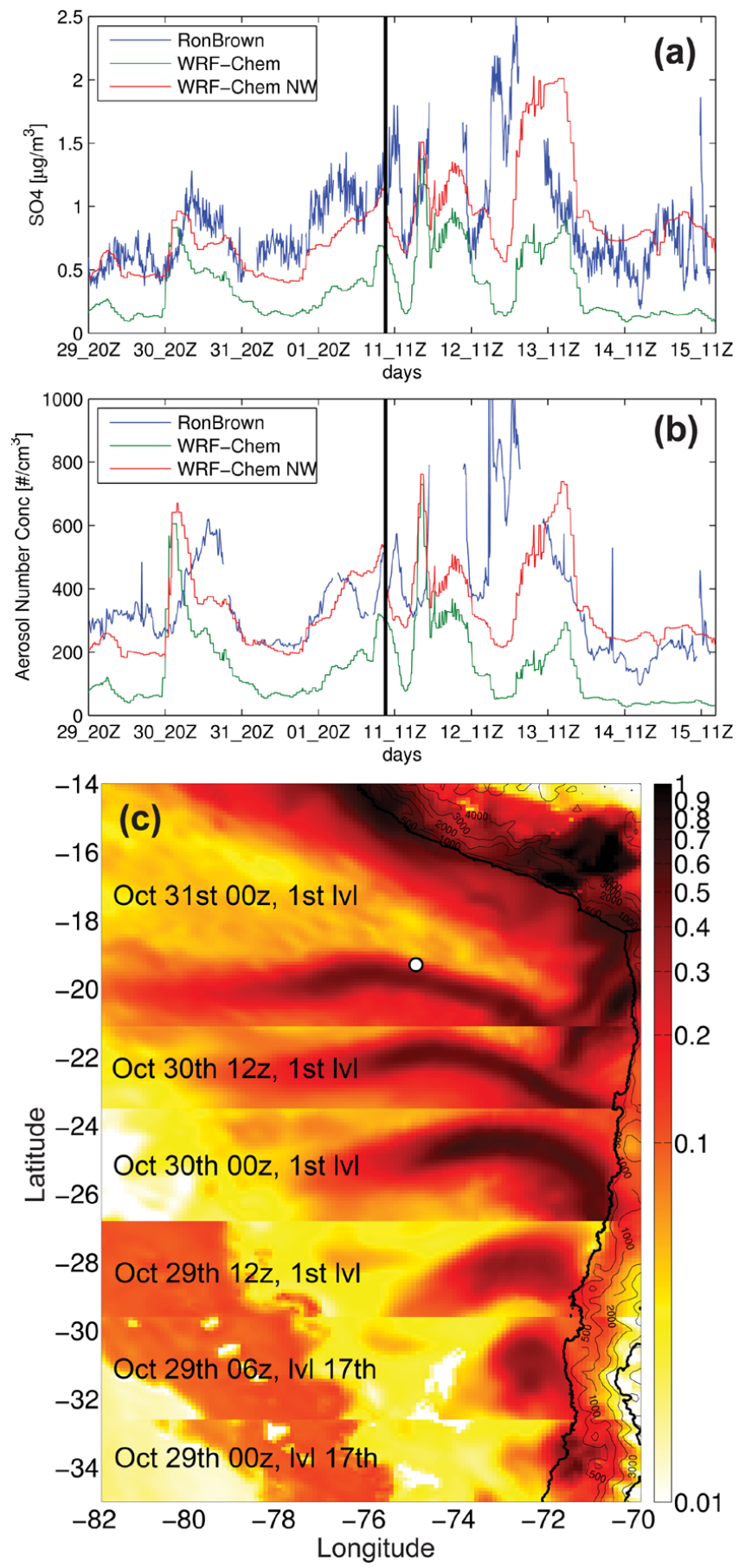

Fig. 8. (a) Time series for observed and modeled $\mathrm{SO}_{4}$. (b) Time series for observed and modeled aerosol number concentration for diameters over $13 \mathrm{~nm}$ and $40 \mathrm{~nm}$ respectively. Black thick lines in (a) and (b) divides both periods that Ron Brown stayed 4 days on $75^{\circ} \mathrm{W}$ : 29 October-1 November and 11-15 November. (c) Composite of NW model second bin (78-156 nm aerosol diameter) $\mathrm{SO}_{4}$ concentration in $\mu \mathrm{g} \mathrm{m}^{-3}$. Each composite follows the same plume since it is emitted on Central Chile until it reaches Ron Brown (marked by a circle) two days after. The two most southern composites are extracted from level 17 ( $\sim 670 \mathrm{~m}$ over sea level) while the rest are extracted from the first model level. Scale is logarithmic. also verified by flight vertical profiles as in Fig. 3) but we still see very high precipitation gradients. Thus, differences in aerosol load might be playing a more important role than previously thought. The enhanced aerosols also participate in cloud feedbacks visible in satellite retrievals of cloud properties. Figure 10a shows MODIS-Aqua cloud effective radius for an overpass on a day with a thick cloud deck, where aerosol feedbacks are more pronounced. Figure 10b, c show model results for effective radius and second bin sulfate surface concentrations. Model cloud effective radius clearly decreases when the MBL is dominated by high accumulation mode sulfate concentrations, following a similar shape to the plume, which can also be observed in the MODIS overpass. The scene shows two distinct plumes coming from Central Chile: an older one between $23^{\circ} \mathrm{S}$ and $20^{\circ} \mathrm{S}$ and a fresher one in between $29^{\circ} \mathrm{S}$ and $25^{\circ} \mathrm{S}$, both showing a decrease in cloud effective radius in both model and the observations. These findings highlights the need to consider aerosol interactions and transport from far-away sources in high-resolution studies and NWP applications over the region and similar persistent coastal stratocumulus in eastern boundary tropical and subtropical areas.

\subsection{Assessing differences due to model configuration}

WRF-Chem is a community model with several choices of parameterizations to represent various processes (Skamarock et al., 2008). These choices result in different model configurations, which can produce different predictions. For example, there are two microphysics schemes that can be used to study aerosol indirect effects in WRFChem v3.3: the Lin scheme (used in this study); and the Morrison scheme (Q. Yang et al., 2011; Morrison and Pinto, 2005). Figure 11 shows results from a sensitivity column study where both schemes were run until reaching stable conditions as a function of number of droplets. Significant differences of over an order of magnitude are found in rain rates between both schemes. For the VOCALS-REx case of study, the Lin scheme rain rates showed good performance (Fig. 6), while the Morrison scheme showed under-prediction (Q. Yang et al., 2011), in accordance with Fig. 11. The higher rain rates in our study can also explain the larger underprediction of sulfate mass and aerosol number concentration by the base model (Figs. 1 and 3) compared to the Q. Yang et al. (2011) study. We hypothesize that the main cause of the rain mismatch is the different autoconversion (cloud droplets to rain conversion) parameterization used in both schemes. The Morrison scheme uses Khairoutdinov and Kogan (2000) parameterization, which uses regressed coefficients (multiplicative and power laws) from cloud drop size spectra predicted by LES simulations, which shows a linear behavior in the $\log$ scale (Fig. 11a); while the Lin scheme uses Liu et al. (2005) which introduces a threshold function which depends on droplet number concentration that is responsible for the curve shape and rain suppression in Fig. 11a. On the 


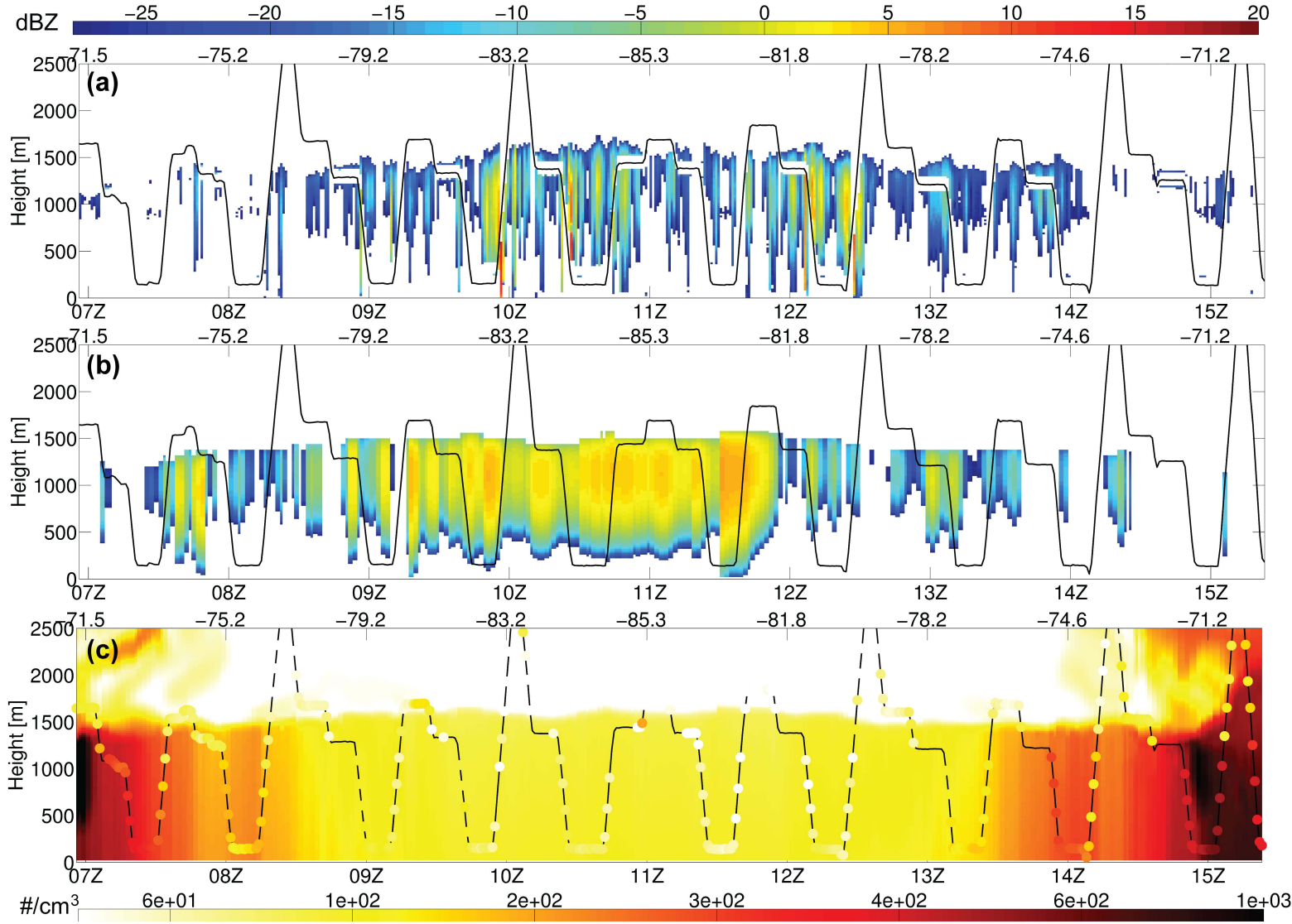

Fig. 9. Curtain plots for radar reflectivity (Z, in dBZ) and accumulation mode aerosol number concentration (\# $\mathrm{cm}^{-3}$ ) for C-130 flight RF05 on 25 October. (a) and (b) shows radar observed and NW model $Z$ while (c) shows NW model as the curtain and one minute average PCASP observations as colored circles. Observed Z and PCASP aerosol are 1 min averages. Model $Z$ is computed according to Appendix A. Solid lines represent flight track with the line becoming segmented on (c) every time there is a PCASP observation. For all panels, bottom scale is time in hours and top scale is longitude in degrees.
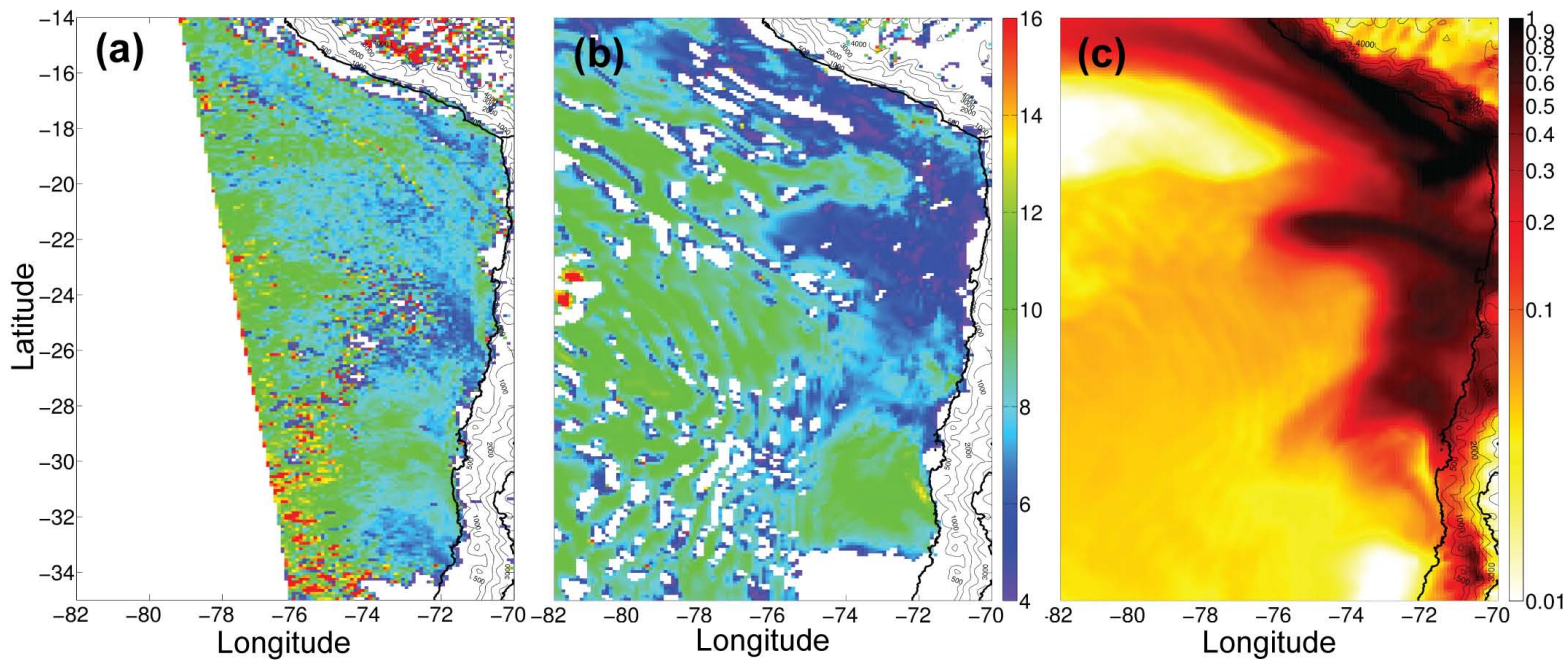

Fig. 10. Horizontal plots of cloud effective radius ( $\mu \mathrm{m}, \mathbf{a}$ and $\mathbf{b})$ and first level, second bin ( $78-156 \mathrm{~nm}$ aerosol diameter) $\mathrm{SO}_{4}$ concentration $\left(\mu \mathrm{g} \mathrm{m}^{-3}, \mathbf{c}\right)$. (a) shows MODIS-AQUA cloud effective radius for 16 October 17:00 UTC overpass while (b) and (c) shows NW model results for the same time. Model cloud effective radius is computed for the cloud top. 


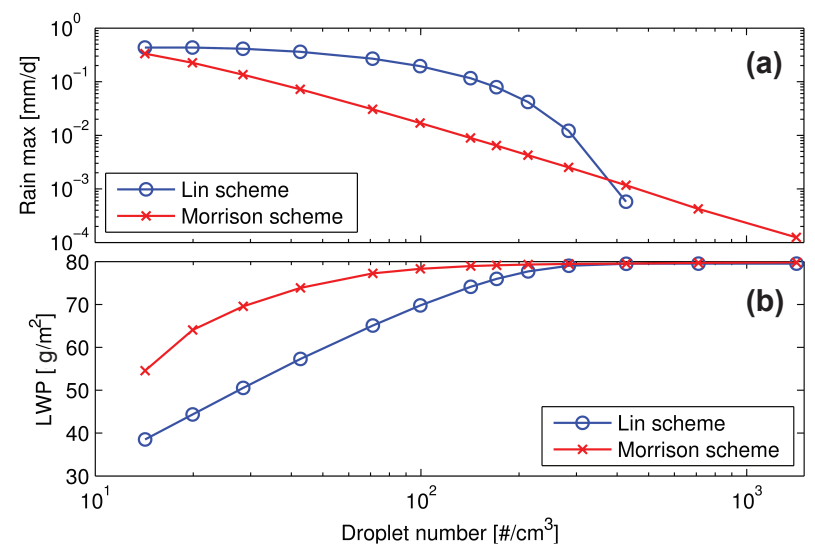

Fig. 11. Results from column study for comparing Lin and Morrison microphysics schemes for a profile on $\left(80^{\circ} \mathrm{W}, 20^{\circ} \mathrm{S}\right)$ at 00:00 UTC on 28 October 2008. (a) shows maximum rain rate per profile while (b) shows liquid water path (LWP) per profile. Each profile is run with a different droplet number concentration using a $12 \mathrm{~s}$ time step for enough time to reach stable conditions. For (a), missing points means rain rate equal to zero.

other hand, the Morrison scheme shows higher liquid water content (Fig. 11b), which is not completely explained by the lower precipitation, as LWP differences are still present when rain rates are similar for low number of droplets. This is also coherent with the fact that Q. Yang et al. (2011) shows better agreement to MODIS LWP than our study, where this configuration under-predicts it.

Full double moment microphysics schemes (Lin scheme is double moment for cloud water only) are necessary to improve process representation in models (e.g., Morrison et al., 2009). As autoconversion seems to be generating low performance in rain rates, we propose to implement and test the Liu et al. (2005) parameterization in the Morrison scheme. The implementation has to come along with the inclusion of aerosol re-suspension due to rain evaporation on the wet deposition scheme to avoid the MBL aerosol biases seen in Figs. 1 and 3.

\section{Conclusions}

There is an imperative need for reducing uncertainty and improving the atmospheric models used in studies of aerosolcloud interactions at scales needed for NWP, air quality predictions, and policy assessments. In this context, several intensive measurement campaigns have been carried out to improve our understanding of aerosol and cloud interactions and they provide an extensive data base for use in testing and improving models. In this work we test the regional model WRF-Chem for the VOCALS-REx campaign which focused on studying the persistent stratocumulus deck on the South East Pacific, off the shore of Chile and Peru. Starting from the fact that the inclusion of aerosol cloud inter- actions in the model are important to represent processes in this region (Q. Yang et al., 2011), we perform model simulations designed to address the questions: what are the effects on cloud dynamics and microphysics from changing the subcloud aerosol loads? And do these effects bring model results closer to observations when aerosol loads are in better agreement to measurements? To address these questions results from two model simulations, with (base) and without wet deposition (NW) were analyzed. Both runs represent an incomplete modeling picture, as the base run lacks aerosol resuspension (which is important in drizzling stratocumulus), and excluding wet deposition means neglecting a known removal process. These simulations produce significant differences in aerosol amounts, particularly in the remote zone where sulfate mass and accumulation mode aerosol number distributions do not overlap with each other and can be one order of magnitude different. Observed aerosol mass and number are usually closer to the NW results, because the model wet deposition process irreversibly removes aerosol even for evaporating rain. Little surface rain was observed during the campaign, so evaporation of drizzle drops is a likely source of sub-cloud aerosols. The increase in aerosol number in NW generate a significant difference between the models in terms of marine boundary layer (MBL) dynamics and cloud microphysics, in accordance to warm clouds aerosol indirect effects. These include an increased number of cloud droplets (Twomey, 1974) showing no overlap of the inner quartiles from the two models in the remote zone; increased MBL and cloud heights (Pincus and Baker, 1994) reaching up to $200 \mathrm{~m}$ differences; drizzle suppression on average concentrations and on number of detections; increased liquid water content and increased cloud lifetime (Albrecht, 1989); which helps answer the first question. MBL dynamics and cloud microphysics observed values are usually closer to NW or at least fall in between both models showing that better aerosol statistical performance lead to changes in the right direction, which helps answer the second question. This study demonstrates the capabilities of the WRF-Chem model to simulate aerosol/cloud interactions, particularly regarding the activation routine, which simulates number of droplet concentrations more accurately when sub-cloud aerosol loads more closely match observations. However, the model needs further improvements to address issues such as aerosol resuspension in rain wet removal, overestimation in oceanic DMS and sea-salt emissions, increased cloud driven $\mathrm{SO}_{2}$ to sulfate conversion and move from bulk to sectional/modal aqueous chemistry. Also, an assessment of model differences when using distinct WRF-Chem configurations shows these seem to be related to the microphysics schemes, specifically to different autoconversion parameterizations which can generate over an order of magnitude disagreement on rain rates predictions for the same conditions.

Besides performing campaign averaged comparisons, we quantified local model performance for stratocumulus properties and their hourly evolution against ship-based 
measurements (NOAA Ron Brown), three aircraft observations (NSF C-130, DoE G-1, FAAM BAe-146) and satellite retrievals (MODIS) using them to explain how aerosols and model processes affect system response. For instance, hourly evolution of cloud heights was evaluated showing a good model performance for the diurnal cycle and different synoptic conditions with the exception of periods where the model is not able to recover from the underestimated MBL height found on the boundary conditions. Also, an episodic study was performed showing that anthropogenic sources from Central Chile substantially changed aerosol mass and number, rain and cloud optical properties over the ocean both in modeled and observed values, showing that indirect effects might be playing a more important role in modulating cloud properties and dynamics than stated in previous studies.

In our analysis we have attempted to perform a complete multi-platform evaluation for a regional simulation of clouds and aerosols, where we included VOCALS-REx observations which were not compared to models previously, such as decoupling state, trace gas concentrations (carbon monoxide, ozone), cloud aerosol composition, cloud water ionic balance and radar reflectivities. These are all crucial to fully quantifying regional model performance in this tightly coupled system. In order to provide quantification to this evaluation, we introduced a new metric for assessing model performance that uses box and whisker plots. This metric is independent of the variable being analyzed, thus allows doing performance cross-comparison in between different models and variables.

Together with improving model issues already mentioned, future work should be focused on continuing to validate models with aerosol and cloud interactions from measurement campaigns in other locations, as conditions for each region vary extensively. Also, several observation platforms such as close to shore flights (NERC Dornier 228 and CIRPAS Twin Otter) and inland measurements (Iquique, Paposo and Paranal sites) were not considered as the modeling was too coarse for their use $\left(12 \mathrm{~km}^{2}\right.$ grid cells). Thus, finer resolution studies for the same area are needed to exploit these data (4-1 km² grid cells). These studies help to better quantify the uncertainties in models, that need to be considered when these models are used as tools for policy makers and for weather and air quality forecasts.

\section{Appendix A}

\section{Model radar reflectivity}

The Lin microphysics scheme implemented in WRF-Chem uses an exponential distribution for rain droplets (Chen and Sun, 2002):

$N(D)=N_{0} \exp (-\Lambda D)$

$$
\Lambda=\left(\frac{\pi \rho_{\mathrm{W}} N_{0}}{\rho q_{\mathrm{r}}}\right)^{1 / 4}
$$

Where $N_{0}$ is the intercept parameter, $\Lambda$ the slope parameter, $\rho_{\mathrm{w}}$ and $\rho$ water and air densities respectively, and $q_{\mathrm{r}}$ the rain water content. Radar reflectivity $(Z)$ is computed as the sixth moment of the rain drop distribution as:

$Z=\int_{0}^{\infty} D^{6} N(D) d D$

which is only valid for Rayleigh scattering regime. As the radar used in this study is W-band $(94 \mathrm{GHz}$ frequency, $\sim 3 \mathrm{~mm}$ wavelength) then Rayleigh scattering might not be valid for droplets over $0.5 \mathrm{~mm}$ (O'Connor et al., 2004). Instead, we use Mie calculations to obtain $Z$ (Arai et al., 2005):

$Z_{\text {Mie }}=\frac{\lambda^{4}}{\pi^{5}|K|^{2}} \int_{0}^{\infty} \sigma_{\text {Mie }} N(D) d D$

Where $\lambda$ is the radar wavelength, $K$ the absorption coefficient of water and $\sigma_{\text {Mie }}$ the backscattering cross-section, which is a function of droplet diameter and radar wavelength. Then, as $N_{0}$ is fixed for the Lin scheme $\left(8 \mathrm{e}+6 m^{4}\right), Z_{\text {Mie }}$ can be computed as a function of rain water content by numerically integrating this equation. For each diameter, $\sigma_{\text {Mie }}$ is computed using Mätzler (2002) code which is based on the Appendix of Bohren and Huffman (1983).

Acknowledgements. We thank all people and organizations that participated in the VOCALS-REx campaign, generating and allowing us to use the complete and comprehensive data set. Special thanks to Timothy Bates, Paquita Zuidema and Ludovic Bariteau for helping interpret and compare observational data, to William Gustafson and Jerome Fast for comments on modeling and to two anonymous reviewers for their constructive comments. Ron Brown, C-130 and G-1 measurements were obtained from the VOCALS data archive NCAR/EOL, which is sponsored by the National Science Foundation (NSF). MODIS data was obtained from the NASA Langley Research Center Atmospheric Science Data Center. Special thanks to the staff of the NCAR Research Aviation Facility for supporting the deployment of the C130 and the staff of the UWYO King Air national facility for enabling the deployment of the WCR and WCL onboard the C130 during VOCALS-REx. We also thank the UK Natural Environment Research Council (NERC) for funding the VOCALS UK contingent to the project (grant ref: NE/F019874/1) and the NERC Facility for Airborne and Atmospheric Measurment (FAAM) and Direct Flight and Avalon for operational support of the BAe-146 aircraft. This work was carried out with the aid of NSF grants 0748012 and 0745986, grant number UL1RR024979 from the National Center for Research Resources (NCRR), a part of the National Institutes of Health (NIH), FONDECYT Iniciación grant 11090084, and Fulbright-CONICYT scholarship number 15093810. Its contents are solely the responsibility of the authors and do not necessarily represent the official views of the founding institutions.

Edited by: R. Wood 


\section{References}

Abdul-Razzak, H. and Ghan, S. J.: A parameterization of aerosol activation. 3. Sectional representation, J. Geophys. Res., 107, 4026, doi:10.1029/2001JD000483, 2002.

Abel, S. J., Walters, D. N., and Allen, G.: Evaluation of stratocumulus cloud prediction in the Met Office forecast model during VOCALS-REx, Atmos. Chem. Phys., 10, 10541-10559, doi:10.5194/acp-10-10541-2010, 2010.

Albrecht, B. A.: Aerosols, cloud microphysics, and fractional cloudiness, Science, 245, 1227-1230, 1989.

Allen, G., Coe, H., Clarke, A., Bretherton, C., Wood, R., Abel, S. J., Barrett, P., Brown, P., George, R., Freitag, S., McNaughton, C., Howell, S., Shank, L., Kapustin, V., Brekhovskikh, V., Kleinman, L., Lee, Y.-N., Springston, S., Toniazzo, T., Krejci, R., Fochesatto, J., Shaw, G., Krecl, P., Brooks, B., McMeeking, G., Bower, K. N., Williams, P. I., Crosier, J., Crawford, I., Connolly, P., Allan, J. D., Covert, D., Bandy, A. R., Russell, L. M., Trembath, J., Bart, M., McQuaid, J. B., Wang, J., and Chand, D.: South East Pacific atmospheric composition and variability sampled along $20^{\circ} \mathrm{S}$ during VOCALS-REx, Atmos. Chem. Phys., 11, 5237-5262, doi:10.5194/acp-11-5237-2011, 2011.

Andrejczuk, M., Grabowski, W. W., Gadian, A., and Burton, R.: Limited-area modelling of stratocumulus over SouthEastern Pacific, Atmos. Chem. Phys. Discuss., 11, 25517-25556, doi:10.5194/acpd-11-25517-2011, 2011.

Andronache, C., Donner, L. J., Seman, C. J., Ramaswamy, V., and Hemler, R. S.: Atmospheric sulfur and deep convective clouds in tropical Pacific: a model study, J. Geophys. Res., 104, 40054024, 1999.

Arai, K., Liang, X. M., and Liu, Q.: Method for estimation of rain rate with Rayleigh and Mie scattering assumptions on the $Z$ $R$ relationship for different rainfall types, Adv. Space Res., 36, 813-817, 2005.

Bator, A. and Collett Jr., J. L.: Cloud chemistry varies with drop size, J. Geophys. Res., 102, 28071-28078, doi:10.1029/97JD02306, 1997

Benedict, K. B., Lee, T., and Collett Jr., J. L.: Cloud water composition over the Southeastern Pacific Ocean during the VOCALS Regional Experiment, Atmos. Environ.,46, 104-114, doi:10.1016/j.atmosenv.2011.10.029, 2012.

Berner, A. H., Bretherton, C. S., and Wood, R.: Large-eddy simulation of mesoscale dynamics and entrainment around a pocket of open cells observed in VOCALS-REx RF06, Atmos. Chem. Phys., 11, 10525-10540, doi:10.5194/acp-11-10525-2011, 2011.

Bohren, C. F. and Huffman, D. R.: Absorption of Light by Small Particles, Wiley, New York, 1983.

Bond, T. C., Streets, D. G., Yarber, K. F., Nelson, S. M., Woo, J.H., and Klimont, Z.: A technology-based global inventory of black and organic carbon emissions from combustion, J. Geophys. Res., 109, D14203, doi:10.1029/2003JD003697, 2004.

Bretherton, C. S., Wood, R., George, R. C., Leon, D., Allen, G., and Zheng, X.: Southeast Pacific stratocumulus clouds, precipitation and boundary layer structure sampled along $20^{\circ} \mathrm{S}$ during VOCALS-REx, Atmos. Chem. Phys., 10, 10639-10654, doi:10.5194/acp-10-10639-2010, 2010.

Cess, R. D., Potter, G. L., Blanchet, J. P., Boer, G. J., Ghan, S. J., Kiehl, J. T., Le Treut, H., Li, Z. X., Liang, X. Z., Mitchell, J. F. B., and others: Interpretation of cloud-climate feedback as produced by 14 atmospheric general circulation models, Science,
245, 513-516, 1989.

Chand, D., Hegg, D. A., Wood, R., Shaw, G. E., Wallace, D., and Covert, D. S.: Source attribution of climatically important aerosol properties measured at Paposo (Chile) during VOCALS, Atmos. Chem. Phys., 10, 10789-10801, doi:10.5194/acp-1010789-2010, 2010.

Chapman, E. G., Gustafson Jr., W. I., Easter, R. C., Barnard, J. C., Ghan, S. J., Pekour, M. S., and Fast, J. D.: Coupling aerosolcloud-radiative processes in the WRF-Chem model: Investigating the radiative impact of elevated point sources, Atmos. Chem. Phys., 9, 945-964, doi:10.5194/acp-9-945-2009, 2009.

Chen, S.-H. and Sun, W.- Y.: A one-dimensional time dependent cloud model, J. Meteorol. Soc. Japan, 80, 99-118, 2002.

Chen, Y.-C., Xue, L., Lebo, Z. J., Wang, H., Rasmussen, R. M., and Seinfeld, J. H.: A comprehensive numerical study of aerosolcloud-precipitation interactions in marine stratocumulus, Atmos. Chem. Phys., 11, 9749-9769, doi:10.5194/acp-11-9749-2011, 2011.

Chou, M. D., Suarez, M. J., Ho, C. H., Yan, M. M. H., and Lee, K. T.: Parameterizations for cloud overlapping and shortwave single-scattering properties for use in general circulation and cloud ensemble models, J. Climate, 11, 202-214, 1998.

Comstock, K. K., Wood, R., Yuter, S. E., and Bretherton, C. S.: Reflectivity and rain rate in and below drizzling stratocumulus, Q. J. Roy. Meteorol. Soc., 130, 2891-2918, 2004.

Corvalán, R. M., Osses, M., Urrutia, C. M., Gonzalez, P. A.: Estimating traffic emissions using demographic and socio-economic variables in 18 Chilean urban areas, Popul. Environ., 27, 63-87, 2005.

Davies, D. K., Ilavajhala, S., Wong, M. M., and Justice, C. O.: Fire information for resource management system: archiving and distributing MODIS active fire data, IEEE T. Geosci. Remote Sens., 47, 72-79, doi:10.1109/TGRS.2008.2002076, 2009.

de Szoeke, S. P., Fairall, C. W., Wolfe, D. E., Bariteau, L., and Zuidema, P.: Surface flux observations on the southeastern tropical pacific ocean and attribution of SST errors in coupled oceanatmosphere models, J. Climate, 23, 4152-4174, 2010.

DICTUC: Actualización del Invexntario de Emisiones de Contaminantes Atmosféricos en la Región Metropolitana 2005, Prepared for Chilean Ministry of Environment, Santiago, Chile, 2007.

Easter, R. C., Ghan, S. J., Zhang, Y., Saylor, R. D., Chapman, E. G., Laulainen, N. S., Abdul-Razzak, H., Leung, L. R., Bian, X., and Zaveri, R. A.: MIRAGE: Model description and evaluation of aerosols and trace gases, J. Geophys. Res., 109, D20210, doi:10.1029/2004JD004571, 2004.

Emmons, L. K., Walters, S., Hess, P. G., Lamarque, J.-F., Pfister, G. G., Fillmore, D., Granier, C., Guenther, A., Kinnison, D., Laepple, T., Orlando, J., Tie, X., Tyndall, G., Wiedinmyer, C., Baughcum, S. L., and Kloster, S.: Description and evaluation of the Model for Ozone and Related chemical Tracers, version 4 (MOZART-4), Geosci. Model Dev., 3, 43-67, doi:10.5194/gmd3-43-2010, 2010.

Errico, R. M., Bauer, P., and Mahfouf, J. F.: Issues regarding the assimilation of cloud and precipitation data, J. Atmos. Sci., 64, 3785-3798, 2007.

Fahey, K. M. and Pandis, S. N.: Optimizing model performance: variable size resolution in cloud chemistry modeling, Atmos. Environ., 35, 4471-4478, 2001.

Fast, J. D., Gustafson Jr., W. I., Easter, R. C., Zaveri, R. A., 
Barnard, J. C., Chapman, E. G., Grell, G. A., and Peckham, S. E.: Evolution of ozone, particulates, and aerosol direct radiative forcing in the vicinity of Houston using a fully coupled meteorology-chemistry-aerosol model, J. Geophys. Res., 111, D21305, doi:10.1029/2005JD006721, 2006.

Feingold, G., Kreidenweis, S. M., Stevens, B., and Cotton, W. R.: Numerical simulations of stratocumulus processing of cloud condensation nuclei through collision-coalescence, J. Geophys. Res., 101, 21391-21402, doi:10.1029/96JD01552, 1996.

Feingold, G., Walko, R. L., Stevens, B., and Cotton, W. R.: Simulations of marine stratocumulus using a new microphysical parameterization scheme, Atmos. Res., 47-48, 505-528, 1998.

Freitas, S. R., Longo, K. M., and Andreae, M. O.: Impact of including the plume rise of vegetation fires in numerical simulations of associated atmospheric pollutants, Geophys. Res. Lett., 33, L17808, doi:10.1029/2006GL026608, 2006.

Freitas, S. R., Longo, K. M., Chatfield, R., Latham, D., Silva Dias, M. A. F., Andreae, M. O., Prins, E., Santos, J. C., Gielow, R., and Carvalho Jr., J. A.: Including the sub-grid scale plume rise of vegetation fires in low resolution atmospheric transport models, Atmos. Chem. Phys., 7, 3385-3398, doi:10.5194/acp-7-3385-2007, 2007.

Garreaud, R. D. and Muñoz, R. C.: The low-level jet off the west coast of subtropical South America: structure and variability, Mon. Weather Rev., 133, 2246-2261, 2005.

Ghan, S. J. and Easter, R. C.: Impact of cloud-borne aerosol representation on aerosol direct and indirect effects, Atmos. Chem. Phys., 6, 4163-4174, doi:10.5194/acp-6-4163-2006, 2006.

Gong, S., Barrie, L. A., and Blanchet, J.-P.: Modeling sea salt aerosols in the atmosphere. 1: Model development, J. Geophys. Res., 102, 3805-3818, 1997.

Graß1, H.: Possible changes of planetary albedo due to aerosol particles, in: Man's Impact on Climate, edited by: Bach, W., Pankrath, J., and Kellogg, W., Elsevier, New York, 1979.

Grell, G. A., Peckham, S. E., Schmitz, R., McKeen, S. A., Frost, G., Skamarock, W. C., and Eder, B.: Fully coupled "online" chemistry within the WRF model, Atmos. Environ. 39, 6957-6975, 2005.

Guenther, A., Karl, T., Harley, P., Wiedinmyer, C., Palmer, P. I., and Geron, C.: Estimates of global terrestrial isoprene emissions using MEGAN (Model of Emissions of Gases and Aerosols from Nature), Atmos. Chem. Phys., 6, 3181-3210, doi:10.5194/acp-63181-2006, 2006.

Gustafson Jr., W. I., Chapman, E. G., Ghan, S. J., Easter, R. C., and Fast, J. D.: Impact on modeled cloud characteristics due to simplified treatment of uniform cloud condensation nuclei during NEAQS 2004, Geophys. Res. Lett., 34, L19809, doi:10.1029/2007GL030021, 2007.

Hawkins, L. N., Russell, L. M., Covert, D. S., Quinn, P. K., and Bates, T. S.: Carboxylic acids, sulfates, and organosulfates in processed continental organic aerosol over the Southeast Pacific Ocean during VOCALS-REx 2008, J. Geophys. Res., 115, D13201, doi:10.1029/2009JD013276, 2010.

Hind, A. J., Rauschenberg, C. D., Johnson, J. E., Yang, M., and Matrai, P. A.: The use of algorithms to predict surface seawater dimethyl sulphide concentrations in the SE Pacific, a region of steep gradients in primary productivity, biomass and mixed layer depth, Biogeosciences, 8, 1-16, doi:10.5194/bg-8-1-2011, 2011.

Hoffmann, M. R. and Calvert, J. G.: Chemical transformation modules for Eulerian acid deposition models, Vol. 2, in: The Aqueous-Phase Chemistry, EPA/600/3-85/017, US Environmental Protection Agency, Research Triangle Park, NC, 1985.

Jones, C. R., Bretherton, C. S., and Leon, D.: Coupled vs. decoupled boundary layers in VOCALS-REx, Atmos. Chem. Phys., 11, 7143-7153, doi:10.5194/acp-11-7143-2011, 2011.

Jorquera, H. and Castro, J.: Analysis of urban pollution episodes by inverse modeling, Atmos. Environ. 44, 42-54, 2010.

Kanakidou, M., Seinfeld, J. H., Pandis, S. N., Barnes, I., Dentener, F. J., Facchini, M. C., Van Dingenen, R., Ervens, B., Nenes, A., Nielsen, C. J., Swietlicki, E., Putaud, J. P., Balkanski, Y., Fuzzi, S., Horth, J., Moortgat, G. K., Winterhalter, R., Myhre, C. E. L., Tsigaridis, K., Vignati, E., Stephanou, E. G., and Wilson, J.: Organic aerosol and global climate modelling: a review, Atmos. Chem. Phys., 5, 1053-1123, doi:10.5194/acp-51053-2005, 2005.

KAS: "Análisis General del Impacto Social y Económico de la Norma de Emisión Para Termoeléctricas." Chilean Ministry of the Environment, available at: http://www.sinia.cl/1292/ articles-44963_informe_final_term.pdf, last access: November 2011, 2009.

Kazil, J., Wang, H., Feingold, G., Clarke, A. D., Snider, J. R., and Bandy, A. R.: Modeling chemical and aerosol processes in the transition from closed to open cells during VOCALS-REx, Atmos. Chem. Phys., 11, 7491-7514, doi:10.5194/acp-11-74912011, 2011.

Khairoutdinov, M. and Kogan, Y.: A new cloud physics parameterization in a large-eddy simulation model of marine stratocumulus, Mon. Weather Rev. 128, 229-243, 2000.

King, M. D., Platnick, S., Hubanks, P. A., Arnold, G. T., Moody, E. G., Wind, G., and Wind, B.: Collection 005 change summary for the MODIS cloud optical property (06_OD) algorithm, available at: http://modis-atmos.gsfc.nasa.gov/C005 Changes/C005_CloudOpticalProperties_ver311.pdf, last accesse: November 2011, 2006.

Kleinman, L. I., Daum, P. H., Lee, Y.-N., Lewis, E. R., Sedlacek III, A. J., Senum, G. I., Springston, S. R., Wang, J., Hubbe, J., Jayne, J., Min, Q., Yum, S. S., and Allen, G.: Aerosol concentration and size distribution measured below, in, and above cloud from the DOE G-1 during VOCALS-REx, Atmos. Chem. Phys., 12, 207-223, doi:10.5194/acp-12-207-2012, 2012.

Koren, I., Martins, J. V., Remer, L. A., and Afargan, H.: Smoke invigoration versus inhibition of clouds over the Amazon, Science, 321, 946-949, 2008.

Liepert, B. G.: Observed reductions of surface solar radiation at sites in the United States and worldwide from 1961 to 1990 , Geophys. Res. Lett., 29, 1421, doi:10.1029/2002GL014910, 2002.

Liss, P. S. and Merlivat, L.: Air-sea gas exchange rates: Introduction and synthesis, in: The role of air-sea exchange in geochemical cycling, edited by: Buat-Menard, P., 113-127, 1986.

Liu, Y., Daum, P. H., and McGraw, R. L.: Size truncation effect, threshold behavior, and a new type of autoconversion parameterization, Geophys. Res. Lett., 32, L11811, doi:10.1029/2005GL022636, 2005.

Lohmann, U.: A glaciation indirect aerosol effect caused by soot aerosols, Geophys. Res. Lett., 29, 1052, doi:10.1029/2001GL014 357, 2002. 
Lohmann, U. and Feichter, J.: Global indirect aerosol effects: a review, Atmos. Chem. Phys., 5, 715-737, doi:10.5194/acp-5-7152005, 2005.

Lohmann, U. and Lesins, G.: Stronger constraints on the anthropogenic indirect aerosol effect, Science, 298, 1012-1016, 2002.

Mätzler, C.: MATLAB Functions for Mie Scattering and Absorption, Institut für Angewandte Physik, Research Report No. 200208, Bern, Switzerland, 2002.

Martin, G. M., Johnson, W., and Spice, A.: The measurement and parameterization of effective radius of droplets in warm stratocumulus, J. Atmos. Sci., 51, 1823-1842, 1994.

Martin, L. and Damschen, D. E.: Aqueous oxidation of sulfur dioxide by hydrogen peroxide at low $\mathrm{pH}$, Atmos. Environ., 15, 16151621, doi:10.1016/0004-6981(81)90146-3, 1981.

McArdle, J. V. and Hoffmann, M. R.: Kinetics and mechanism of the oxidation of aquated sulfur dioxide by hydrogen peroxide at low pH, J. Phys. Chem., 87, 5425-5429, 1983.

McFarquhar, G. M., Um, J., Freer, M., Baumgardner, D., Kok, G. L., and Mace, G.: The importance of small ice crystals to cirrus properties: observations from the Tropical Warm Pool International cloud Experiment (TWP-ICE), Geophys. Res. Lett., 57, L13803, doi:10.1029/2007GL029865, 2007.

Mena-Carrasco, M., Ruiz, P., Stambuk, A., Stambuk, L., Granifo, R., and Jerardino, M.: Antecedentes para la Revisión de las Normas Primarias de Calidad de Aire para Dióxido de Azufre, Monóxido de Carbono, Ozono, Dióxido de Nitrógeno. Chilean Ministry of the Environment, Santiago, Chile, 2010.

Mena-Carrasco, M., Oliva, E., Saide, P., Spak, S., de la Maza, C., Osses, M., Tolvett, S., Molina, L. T.: Estimating social and economic benefits from natural gas use in transport and heating in Santiago, Chile, submitted, 2012.

Michel, Y. and Auligné, T.: Inhomogeneous background error modeling and estimation over Antarctica, Mon. Weather Rev., 138, 2229-2252, 2010.

Mitra, S. K., Brinkmann, J., and Pruppacher, H. R.: A wind tunnel study on the drop-to-particle conversion, J. Aerosol Sci., 23, 245-256, doi:10.1016/0021-8502(92)90326-Q, 1992.

Mlawer, E. J., Taubman, S. J., Brown, P. D., Iacono, M. J., and Clough, S. A.: Radiative transfer for inhomogeneous atmosphere: RRTM, a validated correlated- $k$ model for the longwave, J. Geophys. Res., 102, 16663-16682, 1997.

Morrison, H. and Pinto, J. O.: Mesoscale modeling of springtime Arctic mixed-phase stratiform clouds using a new two-moment bulk microphysics scheme, J. Atmos. Sci., 62, 3683-3704, 2005.

Morrison, H., Thompson, G., and Tatarskii, V.: Impact of cloud microphysics on the development of trailing stratiform precipitation in a simulated squall line: comparison of one- and two-moment schemes, Mon. Weather Rev., 137, 991-1007, doi:10.1175/2008mwr2556.1, 2009.

Muñoz, R. C. and Garreaud, R. D.: Dynamics of the low-level jet off the west coast of subtropical South America, Mon. Weather Rev., 133, 3661-3677, 2005.

Nakanishi, M. and Niino, H.: An improved Mellor-Yamada level3 model with condensation physics: its design and verification, Bound.-Lay. Meteorol. 112, 1-31, 2004.

Ntelekos, A. A., Smith, J. A., Donner, L. J., Fast, J. D., Gustafson Jr., W. I., Chapman, E. G., and Krajewski, W. F.: The effects of aerosols on intense convective precipitation in the Northeastern US, Q. J. Roy. Meteor. Soc., 135, 1367-1391, 2009.
O'Connor, E. J., Illingworth, A. J., and Hogan, R. J.: A technique for autocalibration of cloud lidar, J. Atmos. Oceanic Technol., 21, 777-786, 2004.

Olivier, J. G. J., Bouwman, A. F., Van der Maas, C. W. M., and Berdowski, J. J. M.: Emission Database for Global Atmospheric Research (EDGAR), Environ. Monit. Assess., 31, 93-106, 1994.

Otkin, J. A. and Greenwald, T. J.: Comparison of WRF modelsimulated and MODIS-derived cloud data, Mon. Weather Rev., 136, 1957-1970, 2008.

Otkin, J. A., Greenwald, T. J., Sieglaff, J., and Huang, H.-L.: Validation of a large-scale simulated brightness temperature dataset using SEVIRI satellite observations, J. Appl. Meteor. Climatol., 48, 1613-1626, doi:10.1175/2009JAMC2142.1, 2009.

Pincus, R. and Baker, M.: Effect of precipitation on the albedo susceptibility of clouds in the marine boundary layer, Nature, 372, 250-252, 1994.

Rahn, D. A. and Garreaud, R.: Marine boundary layer over the subtropical southeast Pacific during VOCALS-REx - Part 1: Mean structure and diurnal cycle, Atmos. Chem. Phys., 10, 4491-4506, doi:10.5194/acp-10-4491-2010, 2010.

Ramanathan, V., Cess, R. D., Harrison, E. F., Minnis, P., Barkstrom, B. R., Ahmad, E., and Hartmann, D.: Cloud-radiative forcing and climate: results from the earth radiation budget experiment, Science, 243, 57-63, 1989.

Saide, P., Osses, A., Gallardo, L., and Osses, M.: Adjoint inverse modeling of a $\mathrm{CO}$ emission inventory at the city scale: Santiago de Chile's case, Atmos. Chem. Phys. Discuss., 9, 6325-6361, doi:10.5194/acpd-9-6325-2009, 2009.

Saide, P. E., Carmichael, G. R., Spak, S. N., Gallardo, L., Osses, A. E., Mena-Carrasco, M. A., and Pagowski, M.: Forecasting urban $\mathrm{PM}_{10}$ and $\mathrm{PM}_{2.5}$ pollution episodes in very stable nocturnal conditions and complex terrain using WRFChem CO tracer model, Atmos. Environ., 45, 2769-2780, doi:10.1016/j.atmosenv.2011.02.001, 2011.

Seinfeld, J. and Pandis, S.: Atmospheric Chemistry and Physics, 2nd edn., Wiley, Hoboken, New Jersey, USA, 478-483, 2006.

Shah, S., Rao, B. M., Kumar, P., and Pal, P. K.: Verification of cloud cover forecast with INSAT observation over Western India, J. Earth Syst. Sci., 119, 775-781, 2010.

Shank, L. M., Howell, S., Clarke, A. D., Freitag, S., Brekhovskikh, V., Kapustin, V., McNaughton, C., Campos, T., and Wood, R.: Organic matter and non-refractory aerosol over the remote Southeast Pacific: oceanic and combustion sources, Atmos. Chem. Phys., 12, 557-576, doi:10.5194/acp-12-5572012, 2012.

Skamarock, W. C., Klemp, J. B., Dudhia, J., Gill, D. O., Barker, D. M., Duda, M. G., Huang, X.- Y., Wang, W., and Powers, J. G.: A Description of the Advanced Research WRF, Version 3. Technical Report NCAR/TN475+ST R. National Center for Atmospheric Research Technical Note, Boulder, Colorado, 2008.

Slingo, A.: A GCM parameterization for the shortwave radiative properties of water clouds, J. Atmos. Sci., 46, 1419-1427, 1989.

Solomon, S., Qin, D., Manning, M., Alley, R. B., Berntsen, T., Bindoff, N. L., Chen, Z., Chidthaisong, A., Gregory, J. M., Hegerl, G. C., Heimann, M., Hewitson, B., Hoskins, B. J., Joos, F., Jouzel, J., Kattsov, V., Lohmann, U., Matsuno, T., Molina, M., Nicholls, N., Overpeck, J., Raga, G., Ramaswamy, V., Ren, J., Rusticucci, M., Somerville, R., 
Stocker, T. F., Whetton, P., Wood, R. A., and Wratt, D.: Technical Summary, in: Climate Change 2007: The Physical Science Basis. Contribution of Working Group I to the Fourth Assessment Report of the Intergovernmental Panel on Climate Change, edited by: Solomon, S., Qin, D., Manning, M., Chen, Z., Marquis, M., Averyt, K. B., Tignor, M., and Miller, H. L., Cambridge University Press, Cambridge, New York, 2007.

Spak, S. N., Mena-Carrasco, M. A., and Carmichael, G. R.: Atmospheric transport of anthropogenic oxidized sulfur over the Southeast Pacific during VOCALS REx, CLIVAR Exchanges, 53, 20-21, 2010.

Sun, R., Moorthi, S., Xiao, H., and Mechoso, C. R.: Simulation of low clouds in the Southeast Pacific by the NCEP GFS: sensitivity to vertical mixing, Atmos. Chem. Phys., 10, 12261-12272, doi:10.5194/acp-10-12261-2010, 2010.

Twomey, S.: Pollution and the planetary albedo, Atmos. Environ., 8, 1251-1256, 1974.

Twomey, S.: Aerosols, clouds and radiation, Atmos. Environ. A, 25, 2435-2442, 1991.

Vellore, R., Koracin, D., and Wetzel, M.: A method of improving cloud predictions for real-time forecasting and visualization. Advances in Visual Computing, edited by: Bebis, G., Boyle, R., Parvin, B., Koracin, D., Remagnino, P., Nefian, A., Meenakshisundaram, G., Pascucci, V., Zara, J., Molineros, J., Theisel, H. and Malzbender, T., Springer, Berlin, Germany, 544553, 2006.

Vellore, R., Koracin, D., Wetzel, M., Chai, S., and Wang, Q.: Challenges in Mesoscale prediction of a nocturnal stratocumulustopped marine boundary layer and implications for operational forecasting, Weather Forecast., 22, 1101-1122, 2007.

Wang, H. and Feingold, G.: Modeling mesoscale cellular structures and drizzle in marine stratocumulus. Part I: Impact of drizzle on the formation and evolution of open cells, J. Atmos. Sci., 66, 3257-3275, 2009a.

Wang, H. and Feingold, G.: Modeling mesoscale cellular structures and drizzle in marine stratocumulus. Part II: The microphysics and dynamics of the boundary region between open and closed cells, J. Atmos. Sci., 66, 3257-3275, doi:10.1175/2009JAS3120.1, 2009b.

Wang, H., Feingold, G., Wood, R., and Kazil, J.: Modelling microphysical and meteorological controls on precipitation and cloud cellular structures in Southeast Pacific stratocumulus, Atmos. Chem. Phys., 10, 6347-6362, doi:10.5194/acp-10-6347-2010, 2010.

Wang, S., O’Neill, L. W., Jiang, Q., de Szoeke, S. P., Hong, X., Jin, H., Thompson, W. T., and Zheng, X.: A regional real-time forecast of marine boundary layers during VOCALS-REx, Atmos. Chem. Phys., 11, 421-437, doi:10.5194/acp-11-421-2011, 2011.

Wexler, A. S., Lurmann, F. W., and Seinfeld, J. H.: Modelling urban and regional aerosols - I. Model development, Atmos. Environ., 28, 531-546, 1994.
Wood, R., Mechoso, C. R., Bretherton, C. S., Weller, R. A., Huebert, B., Straneo, F., Albrecht, B. A., Coe, H., Allen, G., Vaughan, G., Daum, P., Fairall, C., Chand, D., Gallardo Klenner, L., Garreaud, R., Grados, C., Covert, D. S., Bates, T. S., Krejci, R., Russell, L. M., de Szoeke, S., Brewer, A., Yuter, S. E., Springston, S. R., Chaigneau, A., Toniazzo, T., Minnis, P., Palikonda, R., Abel, S. J., Brown, W. O. J., Williams, S., Fochesatto, J., Brioude, J., and Bower, K. N.: The VAMOS Ocean-Cloud-Atmosphere-Land Study Regional Experiment (VOCALS-REx): goals, platforms, and field operations, Atmos. Chem. Phys., 11, 627-654, doi:10.5194/acp-11-6272011, 2011.

Wyant, M. C., Wood, R., Bretherton, C. S., Mechoso, C. R., Bacmeister, J., Balmaseda, M. A., Barrett, B., Codron, F., Earnshaw, P., Fast, J., Hannay, C., Kaiser, J. W., Kitagawa, H., Klein, S. A., Köhler, M., Manganello, J., Pan, H.-L., Sun, F., Wang, S., and Wang, Y.: The PreVOCA experiment: modeling the lower troposphere in the Southeast Pacific, Atmos. Chem. Phys., 10, 4757-4774, doi:10.5194/acp-10-4757-2010, 2010.

Yang, M., Blomquist, B. W., and Huebert, B. J.: Constraining the concentration of the hydroxyl radical in a stratocumulus-topped marine boundary layer from sea-to-air eddy covariance flux measurements of dimethylsulfide, Atmos. Chem. Phys., 9, 92259236, doi:10.5194/acp-9-9225-2009, 2009.

Yang, M., Huebert, B. J., Blomquist, B. W., Howell, S. G., Shank, L. M., McNaughton, C. S., Clarke, A. D., Hawkins, L. N., Russell, L. M., Covert, D. S., Coffman, D. J., Bates, T. S., Quinn, P. K., Zagorac, N., Bandy, A. R., de Szoeke, S. P., Zuidema, P. D., Tucker, S. C., Brewer, W. A., Benedict, K. B., and Collett, J. L.: Atmospheric sulfur cycling in the southeastern Pacific longitudinal distribution, vertical profile, and diel variability observed during VOCALS-REx, Atmos. Chem. Phys., 11, 5079-5097, doi:10.5194/acp-11-5079-2011, 2011.

Yang, Q., W. I. Gustafson Jr., Fast, J. D., Wang, H., Easter, R. C., Morrison, H., Lee, Y.-N., Chapman, E. G., Spak, S. N., and Mena-Carrasco, M. A.: Assessing regional scale predictions of aerosols, marine stratocumulus, and their interactions during VOCALS-REx using WRF-Chem, Atmos. Chem. Phys., 11, 11951-11975, doi:10.5194/acp-11-11951-2011, 2011.

Zaveri, R. A. and Peters, L. K.: A new lumped structure photochemical mechanism for large-scale applications, J. Geophys. Res., 104, 30387-30415, 1999.

Zaveri, R. A., Easter, R. C., Fast, J. D., and Peters, L. K.: Model for simulating aerosol interactions and chemistry (MOSAIC), J. Geophys. Res., 113, D13204, doi:10.1029/2007JD008782, 2008.

Zhu, P., Albrecht, B. A., Ghate, V. P., and Zhu, Z.: Multiplescale simulations of stratocumulus clouds, J. Geophys. Res., 115, D23201, doi:10.1029/2010JD014400, 2010. 